\title{
Zaman ve Ürün Miktarı Kısıtlılığı Koşullarındaki Tepkisel Satın Alma Davranışlarının Psikolojik Reaksiyon Kuramı Bağlamında İncelenmesi* (Experimental Research of Consumers Impulse Buying Behaviour at The Time and Product Quantity Scarcity Condition by the Psychological Reactance Theory)
}

\section{Fatma İrem KONYALIOĞLU iD a Ahmet ŞEKERKAYA (D) b}

a İzmir Demokrasi Üniversitesi, İktisadi ve İdari Bilimler Fakültesi, İşletme Bölümü, İzmir, Türkiye. fatmairem.konyalioglu@idu.edu.tr

b İstanbul Üniversitesi, İşletme Fakültesi, Pazarlama Anabilim Dalı, İstanbul, Türkiye. draseker@istanbul.edu.tr

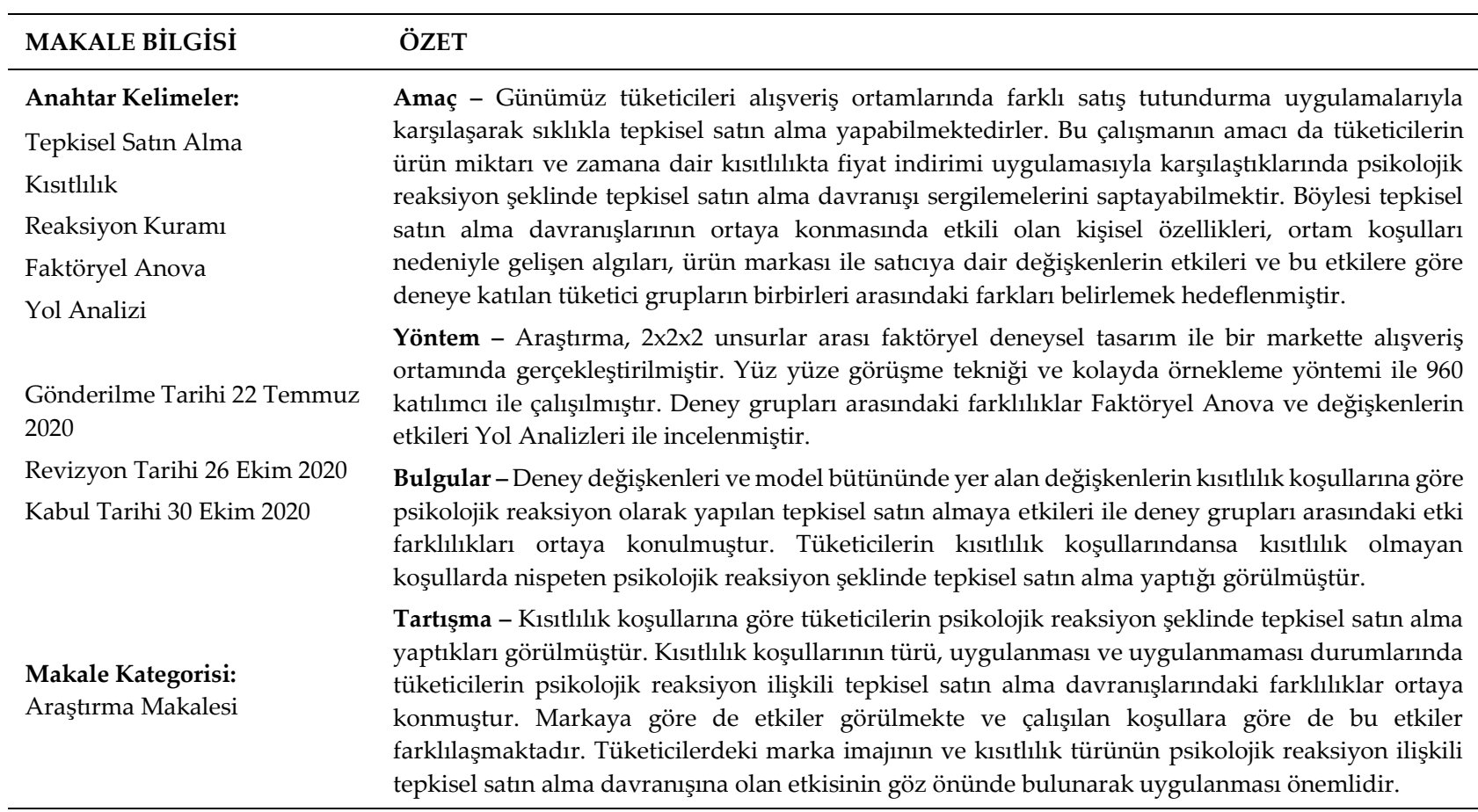

\begin{tabular}{|c|c|}
\hline ARTICLE INFO & ABSTRACT \\
\hline $\begin{array}{l}\text { Keywords: } \\
\text { Impulse Buying } \\
\text { Scarcity } \\
\text { Reactive Theory }\end{array}$ & $\begin{array}{l}\text { Purpose - Contemporary consumers can experience impulse buying by effects of the selling } \\
\text { promotions at retailing environments. The purpose of the study is to determine the impulse buying } \\
\text { behaviour which is experienced by quantity and time scarcity conditions as psychological reactance } \\
\text { to the conditions. The effects of personal properties, purchasing environment and consumer } \\
\text { attitudes on impulse buying and the consumers' differences are the other subjects. }\end{array}$ \\
\hline $\begin{array}{l}\text { Factorial Anova } \\
\text { Path Analysis }\end{array}$ & $\begin{array}{l}\text { Design/methodology/approach - This study is done as the } 2 \times 2 \times 2 \text { factorial design experimental } \\
\text { research which is applied at the retailing environment by the consumers. Factorial Anova and Path } \\
\text { Analysis are applied. The experiment and research model variables effects and the experimental } \\
\text { group differences are analyzed. The face to face survey and convenience sampling methods are } \\
\text { applied with } 960 \text { consumers. }\end{array}$ \\
\hline $\begin{array}{l}\text { Revised } 22 \text { October } 2020 \\
\text { Accepted } 30 \text { Ekim } 2020\end{array}$ & $\begin{array}{l}\text { Findings - The effects of the experimental and model variables are found. The differences are } \\
\text { revealed between the effects that are evaluated by the experimental group designs. The results of } \\
\text { the study show that consumers exhibit impulse buying behaviour as a psychological reaction by non }\end{array}$ \\
\hline
\end{tabular}

*Bu çalışma İstanbul Üniversitesi Sosyal Bilimler Enstitüsü Pazarlama Bilim Dalı'nda tamamlanmış olan “Tüketicilerin Zaman ve Ürün Miktarı Kısıtlılığı Koşullarındaki Tepkisel Satın Alma Davranışlarının Psikolojik Reaksiyon Kuramı Bağlamında İncelenmesine Yönelik Ampirik Bir Çalışma" adlı doktora tezinden üretilmiştir.

Önerilen Atıf/ Suggested Citation

Konyalığlu, F., İ., Şekerkaya, A. (2020). Zaman ve Ürün Miktarı Kısıtlılığı Koşullarındaki Tepkisel Satın Alma Davranışlarının Psikolojik Reaksiyon Kuramı Bağlamında İncelenmesi, İşletme Araştırmaları Dergisi, 12 (4), 3518-3538. 
scarce - free goods rather than scarcity conditions. Impulse buying as psychological reaction can be applied, If the scarcity conditions exist at the market.

Discussion - The consumers impulse buying can be determined as the psychological reactance. If they don't experience scarcity, the reactance impact will be more effective. These effects and differences occur comparable according to brand. Brand image and scarcity conditions will be important for impulse buying If the behaviour has psychological reaction speciality. This is one of the serious issue of the findings.

\section{Giriş}

Kökeninde duygusallıkla bilişselliği birlikte barındırmasıyla 'karmaşık' olarak tanımlanabilen tepkisel satın alma davranışı, perakendecilik sektöründe tüketicilerin sıklıkla sergilediği bir satın alma davranışı türüdür (Berman ve Evans, 2012:39). Bu satın alma davranışı; planlanmadan, tüketicinin uyaranı fark etmesi ile anlık olarak gerçekleşmektedir (Verplanken ve Herabadi, 2001:72). Perakendecilik alanında, tüketicilerin tepkisel satın alma davranışlarına olan etkileri tespit etmek amacıyla farklı stratejilerden söz etmek mümkündür. Bunlar; fiyat indirimi, kısıtlılık uygulamaları, kupon ve promosyon kodu kullanımları olarak siralanabilir (Bellenger vd., 1978:16; Stern, 1962:61-62). Kisitlllık uygulamalarının fiyat indirimi ile birlikte uygulanması tercih edilen yöntemlerden biridir (Spears, 2001:71). Hızlı tüketim ürünlerinden, taşınmaz ürünlere, hizmet ürünlerinden, gayrimenkul satışlarına kadar pek çok ürün tipi için bu tür satış tutundurma stratejileri tercih edilebilir. Kısıtllı1ı koşulları sadece miktar ya da zaman boyutunda olabileceği gibi birlikte de uygulanabilir (Aggarwal vd., 2011:27; Devlin vd., 2007:82; Aggarwal ve Vaidyanathan, 2003:398). Kısıtlılık koşullarını deneyimleyen tüketiciler satın alma hürriyetlerine dair sınırlandırılma hissetmeleri ile yitirilen özgürlüğün tekrar elde edilmesi adına psikolojik reaksiyon sergileyebilirler (Brehm, 1966:9). Satın alma sürecinde edinilebilecek avantajların kısıtlılıkla sunuluyor olması tüketicilerin psikolojik reaksiyon olarak tepkisel satın alma davranışı sergilemelerine neden olabilir (Kim, 2014:17, Lee, 2012:45). Zaman ve ürün miktarı bağlamındaki kısıtlılık koşullarında alışveriş yapan tüketiciler avantajlı satın alma koşulunu yitirmeden ürünü elde etmek amacıyla harekete geçerler. Diğer tüketicilerle aralarında rekabet algılayabilen bu tüketiciler, kısıtlı koşullardan dolayı uyarılma (harekete geçirilme) ve avantajlı satın alma nedeniyle yaşadıkları memnuniyet duygusuyla tepkisel satın alma yapabilirler (Aggarwal vd., 2011:27). Bu çalışmada, üstünde durulmuş olan kavramlar bütünü bağlamında çalışılmıştır. Tüketicilerin alışveriş ortamlarında kısıtlılık koşulları ile karşılaştıklarında psikolojik reaksiyon olarak tepkisel satın alma davranışı sergileme durumunun değerlendirilmesi amaçlanmıştır. Bu çalışmayla, mağaza içinde yapılan fiyat indirimi şeklindeki tutundurma faaliyetlerinin zaman ve ürün miktar kısıtlılık koşulları beraberinde uygulanmasıyla tüketicilerin tepkisel satın alma davranışları incelenmiştir. Tüketicilerin tepkisel satın alma davranışlarını psikolojik reaksiyon olarak sergileyebiliyor olma durumları, kişilere, ürün markasına ve mağazaya dair unsurların etkilerinin belirlemesi amaçlanmıştır. Bu amaca yönelik süreçler mağaza ortamında deneysel olarak uygulanmıştır. Tüketicilerin kısıtlı (zaman ve ürün) koşullarda psikolojik reaksiyon olarak tepkisel şekilde ürün satın alma davranışı Brehm'in 'Psikolojik Reaksiyon Teorisi' bağlamında (Brehm, 1966:9) araştırılmıştır. Bu çalışma; geleneksel perakendecilik ortamında, olağan market alışverişlerindeki tüketicilerle, deneysel tasarım yöntemiyle, ürünün bilfiil satışı ile incelenen konularda Türkiye'de yapılmış ilk çalışmadır.

\section{Literatür İncelemesi}

\section{Tepkisel Satın Alma, Duygu Durum, Bilişsel Süreç ve Tepkisellik}

İnsanların satın alma davranışları farklı şekillerde olabilir. Kişilerin satın alma davranışlarını etkileyen hem içsel (bireylerin kendisine özel) hem dişsal (çevre, ürün, vb. birçok birey dışındaki) etkenler vardır (Wansink, 1994:51). Satın alma koşulları sürekli değişen dünyada tüketici davranışları da değişim göstermektedir. Günümüz tüketicisinin birey olarak gerçekleştirdiği satın alma davranışlarında rasyoneldense duygusal etkilerin ön plana çıtı̆̆ 1 görülmektedir (Kacen vd., 2012:585; Lee ve Kacen, 2008:266; Kacen ve Lee, 2002:162). Tepkisel satın alma davranışı da böylesi şekilde gerçekleşmektedir (Kacen vd., 2012:586). Rasyonel satın alma davranışında, ürünlerin fonksiyonel faydaları göz önünde bulundurulur. Duygusal etkileşimlerle gerçekleşen satın alma davranışında 


\title{
F. İ. Konyalıoğlu - A. Şekerkaya 12/4 (2020) 3518-3538
}

tüketicilerin duygu durumları, kişilikleri özellikleri, ürün ve markaya dair tutumları tüketici davranışının oluşmasında belirleyici role sahiptir (Gardner, 1985:296).

Tüketicilerin içinde bulundukları duygu durumları pek çok davranışlarına yansıdığı gibi satın alma davranışlarını da etkilemektedir (Ünal, 2008:153; Hausman, 2000:405). Ve duygu durumları satın alma davranışları sırasındaki hissediş şekilleriyle de etkileşimlidir (Gardner vd., 2014:329; Richins, 1997:146; Gardner, 1985:295). Özellikle olumlu duygu durumda bulunmak, tüketicilerin hızlıca ve bilişsel süreçlerini olağandan kısaltarak karar verip, hareket etmelerini sağlayabilir. Bu da tepkisel satın alma davranışının olumlu duygu durumda gerçekleşiyor oluşunun anlaşılmasını destekleyicidir (Peterson, 2007:76). Bu bağlamda, tepkisel satın alma davranışının sergilenmesinde etkili iki ana duygu durum ifade edilebilir. Uyarılma olarak adlandırılabileceğimiz 'Harekete Geçirilme' ve 'Memnuniyet' hali olarak bahsi geçen duygu durumlara değinilebilir (Gardner vd., 2014:327; Gardner, 1985:296).

Uyarana maruz kalan tüketiciler bilişsel ve duygusal süreç yaşayarak tepkisel satın alma yapabilmektedirler (Bray, 2008:6). Uyaran algılanıp, uyarılma gerçekleşmesi akabinde kişisel özellikler ve duygu durum etkili şekilde bilişsel (hızlı) bir süreç yaşanır. Bu bağlamda, kestirme yollarla (Heuristics) hızlıca hareket edilerek, bilişsellik sürecinin olabildiğince kısalığıyla tepkisel satın alma gelişebilir (Strack vd., 2006:213). Bu etkinin hızlı bir şekilde bilişsel süreci daha da azaltarak karar almaya ve akabinde ani hareket etmeye güdüleyici olabildiğini söylemek mümkündür. Özellikle, duygusal etkileşimlere açık, hazcı yaklaşımları barındıran kişiler hızlı ve anlık şekilde tepkisel satın alımlar yapabilmektedirler (Baun ve Klein, 2003:294; Kacen ve Lee, 2002:164). Bu tüketicilerin yaşadığı tepkisel satın alma süreci Şekil 1'de yer alan aşamalarla gerçekleşebilmektedir. Tüketiciler duygusallığın baskınlığı, bilişsel değerlendirmelerin azalmasını yaşadıkları zaman rasyonel düşünme yapılarından uzaklaşabilirler. Anlık olarak yaşanabilecek uyarılma sonrasında memnuniyet veya haz duygusuyla hareket (tepkisel davranışı) edebilirler (Bayley ve Nancarrow, 1998:105). Hızlıca gerçekleşecek böylesi tepkisel satın alma davranışının sıklığı ileride gelişebilecek olumsuzlukların göz ardı edilmesine neden olabilir. Keyfi yapılan alışverişlerde tepkisel satın alma davranışının sık olması savurganlığın da yaşanmasına neden olabilmektedir (Gupta, 2013:5; Wood, 1998:302).

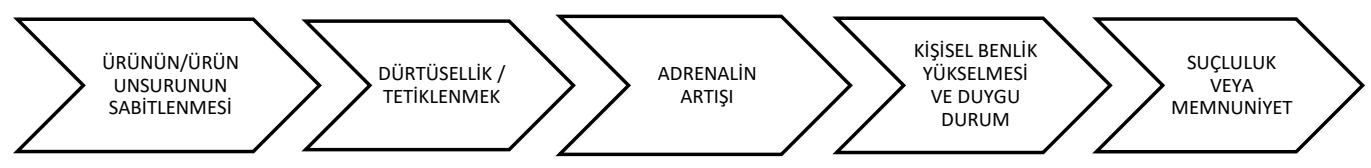

\author{
Şekil 1: Tepkisel Satın Almanın Aşamaları \\ (Bayley ve Nancarrow, 1998)
}

Tepkisel satın alma davranışının sergilenmesinin temelinde tüketicilerin tepkisellik özelliğinin etkisinin olduğu da bilinmektedir. Bu özellik ve onun farkında olmak tepkisel satın alma davranışının kontrol edilmesinde önemli yer tutar (Wingrove ve Bond, 1997:338). Kimi kişiler anlık uyarılma ile hızlıca tatmin olma isteğiyle hazcı davranabilir (Akturan, 2009:65). Tepkisellikleri olanlar nispeten böyledirler (Read, vd., 1999:259). Örneğin, Read ve Van Leeuwen (1998:259) çalışmasında meyve, çikolatalı ürün veya cips sunulduğunda ikram yapılanların \%80'i tepkisellik özelliklerinin etkisiyle çikolatalı ürün ve cips tercih etikleri görülmüştür (Kirby ve Herrnstein, 1995:83).

\section{Tepkisel Satın Alma Davranışı, Perakendecilik ve Marka}

Tüketicilerin tepkisel satın alma davranışına etki eden önemli temel üç ana ve beraberinde alt faktörler vardır (Hausman, 2000:405; Beatty ve Ferrel, 1998:172). Ana faktörler, durumsal (sosyal ve donanımsal boyutta alışveriş ortamı), ürünle ilişkili ve tüketiciyle ilişkilidir (Baumeister, 2002:670). Alt faktörler de; para, zaman, fiziksel ve 


\section{F. İ. Konyalıŏlu - A. Şekerkaya 12/4 (2020) 3518-3538}

zihinsel çabalardır. 'Bir alışverişte tüketici ne kadar az para, zaman, fiziksel ve zihinsel çaba harcarsa o kadar kolay alışveriş yapabilir (Liao vd., 2009:280; Tendai ve Crispen, 2009:103). Tepkisel satın alım, alışverişin kolaylıkla yapılabilirliğine de bağlıdır (Khan vd., 2015:264; Cohen vd., 2008:312). Söz konusu kolaylık, bazı kaynakların tesis edilebilirliğinin esnekliği ve rahatlığıyla ilişkilidir. Bahsi geçen kaynaklar para, zaman, fiziksel ve zihinsel çabalarla bağlantılıdır (Öner, 2011:36; Dinçer, 2010:157; Mihić ve Kursan, 2010:50).

Bahsedilen faktörler ve kaynaklarla yapılan tepkisel satın alma davranışları perakendecilik sektörü için önemli yer tutar. Süpermarketler de tepkisel satın alma davranışının görüldüğü perakende satış kanallarından biridir. Buralarda yapılan alışverişlerin \%60-\%70 tepkisel satın alma davranışıdır (Bell vd., 2011:31; Peter ve Olson, 2010:106). Süpermarketlerde gerçekleşen alışverişlerde; şekerleme ürünlerinin \%85'inin, kozmetik ürünlerinin \%70 inin, ağız bakım ürünlerinin de \%75'inin tepkisel şekilde satın alındığ1 görülmüştür (Solomon, 2006:324). Bu alışverişlerde tüketicilerin zihninde ürün markaların edindiği yer (imaj), kalite algısı ve duygu durumlarına olan etkiler satın alma davranışının gelişiminde önemlidir (Kapferer, 2008; Aaker, 1996:71). Deneyimlerle edinilen olumlu marka imajı ve kalite algısı ile tüketiciler markalara karşı pozitif tutumlar içinde olabilirler (Liao vd., 2009:283; Hansen, 1969:436). Böylesi olumlu tutum içinde oldukları markaları kendilerine yakın bulabilirler (Adelaar vd., 2003:256; Gardner, 1985:295). Tüketicilerin ürün markasına ve alışveriş yaptıkları ortamlara olumlu tutumları tepkisellikle satın alınmalarını teşvik edebilir (Segal ve Podoshen, 2013:194; Byun ve Sternquist, 2012:232, 2011:189, Byun, 2006:81). Satılan ürün miktarı, satın alınma karar süresi ve benzeri kısıtlılık koşullarında var olan olumlu tutumlar etkisiyle psikolojik reaksiyon suretinde tepkisel satın alma davranışlarının sergilenebildiği söylenebilir (Zhang ve Shrum, 2009:846; Clee ve Wicklund, 1980:403).

\section{Kisıtlılık ve Psikolojik Reaksiyon Teorisi}

Kısıtlılık, ürünlerin tüketicilerin ihtiyaçlarını karşılayacak yeterli miktar ve sürede bulunmaması durumudur (Brock, 1968:246). Ekonomi boyutunda kısıtlılığın tanımı göreceli olarak, tüketicilerin kaynaklarının ihtiyaçlarını karşılayacağı miktarda olmaması şeklinde de ifade edilir (Gupta, 2013:6; Li, 1995:16). Kisıtlılık koşulunun, miktara dayalı şekilde 'mevcut olmama', 'az, noksan, sınırlı, limitli olma' ile zaman ilişkili 'tanımlanmış belirli süreli olma' gibi görülebildiği belirtilmiştir (Heath, 2006:13). Kısıtlı ve sınırlı miktardaki kaynaklar sebepli yaşanan durumlar olabilir. Talep sebepli kısıtlılık durumları da vardır. Böylesi koşullarda da talep sebepli rekabet gelişmesiyle 'kısıtlılık koşullarında cazibe arttırıyor olmasına' da işaret edilebilir (Sasikarn, 2012:10; Gierl vd., 2008:45). Tedarikarz boyutunda kısıtlılık hem süre hem de miktar kısıtlılı̆̆ı koşullarının ayrı ayrı veya birlikte uygulanmasına imkan verir (Gierl ve Huettl, 2010:233).

Kısıtlılık ürünlere, ortamlara, olgulara ve durumlara göre sosyal ipucu özelliğiyle etkili olabilmektedir. İkna edicilik veya eylem geliştirmek amacıyla uygulanabilir (Cialdini, 1993:291; Kahneman, 2011:143). Alışveriş ortamlarında tüketicilerin karşılaştıkları kısıtlılık uygulamalarının fizyolojik ve psikolojik etkileri olabilir. Kısıtlılığın etkisi ürün çeşidi ile kısıtlılık türüne göre de değişebilir (Mittone ve Savadari, 2009:454; Gierl vd., 2008:46). Kisıtlılık koşulunda uyarılma ve ortamda rekabet algılanması psikolojik reaksiyon olarak tepkisel satın alma davranışına sebep olabilir. Tüketiciler zaman ve miktar kısıtlılık koşullarını yaşadıkları alışveriş ortamında 'diğerleri almadan, kendilerinin alması' gayretiyle tepkisel satın alma davranışı yapabilirler (Gupta, 2013:125; Grossman ve Mendoza, 2003:757). Veya psikolojik reaksiyon olarak 'Bumerang Etkisi' denilen şekilde satın alma davranışından kaçınabilirler (Bessaraboval vd., 2013:357; Mazis vd., 1973:394).

Kişilerin psikolojik reaksiyon sergilemeleri 'Var olan özgürlügün sürdürülebilirliğinin tehdit edilmesi veya ortadan kaldırılması koşulunda gelişen dürtü hali' olarak ifade edilmiştir (Brehm, 1966:9). Kişiler psikolojik olarak, davranış özgürlüklerinin yitirilmesi, kısıtlanması veya böylesi riskin oluşabileceğini algıladıkları koşulda davranış özgürlüklerini sürdürebilmek veya özgürlüklerini tekrar elde etmek adına harekete geçerler. Bu hale, psikolojik reaksiyon, karşıt tepki, tepkime denilir (Brehm, 1966:9). Örnek olarak; ürünlerin kısıtlı miktar ve sürede temin edilebilir olması cazibesini, edinme isteğini arttırabilir. Böylesi koşulları deneyimleyen tüketiciler psikolojik reaksiyon olarak tepkisel satın alma davranışlarını sergileyebilirler (Kim, 2014:2).

Araştırmanın bütününde tepkisel satın alma davranışı, kısıtlılık koşulları ve psikolojik reaksiyon kuramı birbirleriyle entegre incelenmiştir. Böylelikle, bu üç ana yapıya ve araştırma modelinde yer alan değişkenlere dair 


\section{F. İ. Konyalıŏlu - A. Şekerkaya 12/4 (2020) 3518-3538}

geçmişten günümüze kadar olan ilgili çalışmalar incelenmiştir. Literatür taraması sırasında edinilen bilgiler deneysel çalışmanın ele alınış yöntem ve sürecini aydınlatacak biçimde kuramsal boyutta aktarılmıştır.

\section{Yöntem}

\section{Araştırmanın Kavramsal Modeli ve Değişkenleri}

Günlük market alışveriş ortamında, müşterilerle ve tüketicilerin süpermarket alışverişleri sırasında çoklu etkileşimlerin incelenebilmesi amacıyla deneysel tasarım yöntemiyle çalışılmıştır (Hair vd., 2010:443; Malhotra, 2010:228; Montgomery, 2009:1). Böylelikle, perakendecilik ortamlarında benzer alışveriş koşulları ve değişkenlerle çalışılması durumunda edinilebilecek sonuçlara simülasyon benzeri uygulama ile ışık tutulmuştur.

Deneysel olarak gerçekleştirilen araştırmada çalışılmak üzere ürün belirlenmiştir. Söz konusu ürün "kakaolu fındık kreması" olmuştur. Araştırmanın öncesinde gerçekleştirilen anket çalışmaları sırasında, tüketicilerin tepkisel şekilde aldıkları ürünlerin tespiti ile kararlaştırılmıştır. Bu çalışmanın deneysel tasarımının planlanması sürecinde de yapılan ön çalışmalar doğrultusunda araştırma kapsamına "kakaolu fındık kreması" kategorisinde iki marka dahil edilmiştir. Bu markaların belirlenme sürecinde yapılan ön çalışmalar (anketler, mağaza içi alışveriş süreç gözlemleri ile ölçümleri) ve sektörel veriler (satış rakamları ve perakende kanalı bilgileri) dikkate alınmıştır.

Araştırma modelinde zaman ve miktar kısıtlılığı ile ürün markası deney değişkenleri olarak yer almaktadır. Model bütününde tepkisel satın alma davranışının üç ana temelini teşkil eden kişisel, ürün-markaya ve alışveriş ortamına (mağaza/market) dair değişkenlerle, tüketici duygu durumu ile ortamda algılanan rekabetin tepkisel satın alma davranışı etkileri incelenmektedir.

1- Tüketicilerin kişisel özelliklerine dair değişkenler, tepkisellikle satın alma ve psikolojik reaksiyon sergileme eğilimleridir. Her iki özellik kendi içlerinde bilişsel ve eyleme dair yanlarıyla incelenmiştir.

2- Ürün markası değişkeni kendi içinde üç boyutta araştırma modeli bünyesinde çalışılmıştır. Bunlar, tüketicilerdeki marka imajı, tutumu ve kalite algısı şeklindedir.

3- Alışveriş ortamına ilişkin model değişkeni tüketicilerin markete yönelik değerlendirmeleri olarak incelenmiştir.

Tepkisel satın alma hem bilişsel hem de duygusal etkileşimlerle ortaya çıkar. Ağırlıkla duygusal etkileşimlerin rolünün üstünde durulan tepkisel satın alma davranışının gelişiminde duygu durum etkileri vardır (Gardner vd., 2014:327; Gardner, 1985:296). Duygu duruma dair değişkenler de çalışmanın modelinde önemli yer tutar. Modelde tepkisel satın alma davranışının temelinde yer alan değişkenlerin memnuniyet ve uyarılma duygu durumlarına olan etkileri yer almaktadır.

Araştırma, faktöryel deneysel tasarım şeklinde, her birinin iki düzeyi bulunan üç deney değişkeni ile hazırlanmış ve uygulanmıştır. Deney değişkenleri ürün miktar kısıtlılığı, ürün satın alınabilmesi için tüketicilere tanınan süre (zaman) kısıtlılı̆̆ı ve ürün markası şeklindedir.

Araştırmanın modelinin nihai süreç çıktısı 'tepkisel satın alma davranışına' bütünsel ve çok boyutlu etkilerle, çalışılan gruplar arasındaki etki farklarının değerlendirilmesi şekilde tamamlanmıştır.

\section{Araştırmanın Hipotezleri}

Araştırma modeli bütünündeki ilişkiler, etkileşimler ve farkların tanımlanmasıyla, anlaşılması amacıyla araştırmanın hipotezleri geliştirilmiştir. Geliştirilen hipotezlerde kavramsal modelde yer alan etkiler ve farklılıklar incelenmiştir. Araştırma hipotezleri istatistiksel olarak \%95 güven seviyesinde değerlendirilmiştir.

H1: Araştırmanın kavramsal modelindeki değişkenler tüketicilerin memnuniyete dair duygu durumlarını etkiler.

H1a: Tüketicilerin tepkisel satın alma eğilimi tüketicilerin memnuniyete dair duygu durumlarını etkiler. H1b: Tüketicilerin psikolojik reaksiyon sergileme eğilimi tüketicilerin memnuniyete dair duygu durumunu etkiler. H1c: Tüketicilerdeki ürün markası imajı tüketicilerin memnuniyete dair duygu durumunu etkiler. H1d: 


\section{F. İ. Konyalıŏlu - A. Şekerkaya 12/4 (2020) 3518-3538}

Tüketicilerin ürün markasına dair tutumları tüketicilerin memnuniyete dair duygu durumunu etkiler. H1e: Tüketicilerdeki ürün markasına dair kalite değerlendirmesi tüketicilerin memnuniyete dair duygu durumunu etkiler. H1f: Tüketicilerin alışveriş yaptıkları süpermarkete dair tutumları tüketicilerin memnuniyete dair duygu durumunu etkiler.

H2: Araştırmanın kavramsal modelindeki değişkenler tüketicilerin uyarılmaya dair duygu durumlarını etkiler.

H2a: Tüketicilerin tepkisel satın alma eğilimi tüketicilerin uyarılmaya dair duygu durumunu etkiler. H2b: Tüketicilerin psikolojik reaksiyon sergileme eğilimi tüketicilerin uyarılmaya dair duygu durumunu etkiler. H2c: Tüketicilerdeki ürün markası imajı tüketicilerin uyarılmaya dair duygu durumunu etkiler. H2d: Tüketicilerin ürün markasına dair tutumları tüketicilerin uyarılmaya dair duygu durumunu etkiler. H2e: Tüketicilerdeki ürün markasına dair kalite değerlendirmesi tüketicilerin uyarılmaya dair duygu durumunu etkiler. H2f: Tüketicilerin alışveriş yaptıkları süpermarkete dair tutumları tüketicilerin uyarılmaya dair duygu durumunu etkiler.

H3: Araştırmanın kavramsal modelindeki değişkenler tüketicilerin birbirleri arasında rekabet olduğu algısını etkiler.

H3a: Tüketicilerin tepkisel satın alma eğilimi tüketicilerin birbirleri arasında rekabet olduğu algısını etkiler. H3b: Tüketicilerin psikolojik reaksiyon sergileme eğilimi tüketicilerin birbirleri arasında rekabet olduğu algısını etkiler. H3c: Tüketicilerdeki ürün markası imajı tüketicilerin birbirleri arasında rekabet olduğu algısını etkiler. H3d: Tüketicilerin ürün markasına dair tutumları tüketicilerin birbirleri arasında rekabet olduğu algısını etkiler. H3e: Tüketicilerdeki ürün markasına dair kalite değerlendirmesi tüketicilerin birbirleri arasında rekabet olduğu algısını etkiler. H3f: Tüketicilerin alışveriş yaptıkları süpermarkete dair tutumları tüketicilerin birbirleri arasında rekabet olduğu algısını etkiler.

H4: Araştırmanın kavramsal modelindeki değişkenler tüketicilerin tepkisel satın alma davranışını etkiler.

H4a: Tüketicilerin tepkisel satın alma eğilimi tüketicilerin tepkisel satın alma davranışını etkiler. H4b: Tüketicilerin psikolojik reaksiyon sergileme eğilimi tüketicilerin tepkisel satın alma davranışını etkiler. H4c: Tüketicilerdeki ürün markası imajı tüketicilerin tepkisel satın alma davranışını etkiler. H4d: Tüketicilerin ürün markasına dair tutumları tüketicilerin tepkisel satın alma davranışını etkiler. H4e: Tüketicilerdeki ürün markasına dair kalite değerlendirmesi tüketicilerin tepkisel satın alma davranışını etkiler. H4f: Tüketicilerin alışveriş yaptıkları süpermarkete dair tutumları tüketicilerin tepkisel satın alma davranışını etkiler. H4g: Tüketicilerin algıladıkları rekabet tepkisel satın alma davranışlarını etkiler.

H5: Tüketicilerin duygu durumu rekabet algılamalarını etkiler.

H5a: Tüketicilerin memnuniyete dair duygu durumu rekabet algılamalarını etkiler. H5b: Tüketicilerin uyarılmaya dair duygu durumu rekabet algilamalarını etkiler.

H6: Tüketicilerin duygu durumu tepkisel satın alma davranışlarını etkiler.

H6a: Tüketicilerin memnuniyete dair duygu durumu tepkisel satın alma davranışlarını etkiler. H6b: Tüketicilerin uyarılmaya dair duygu durumu tepkisel satın alma davranışlarını etkiler.

H7: Araştırmanın kavramsal modeli ve modelde yer alan etkiler, deney faktörleri olan zaman kısıtı, miktar kısıtı ve marka türü değişkenlerinin her birine ve deney değişkenlerinin birbirleri arasındaki etkileşimlere bağlı olarak farkl1lı gösterir.

Söz konusu değişkenler arasındaki etkileşimlerin ve farkların incelenebildiği süreci temsil eden araştırmanın kavramsal modeli Şekil 2'de yer almaktadır. 
F. İ. Konyalıŏglu - A. Şekerkaya 12/4 (2020) 3518-3538

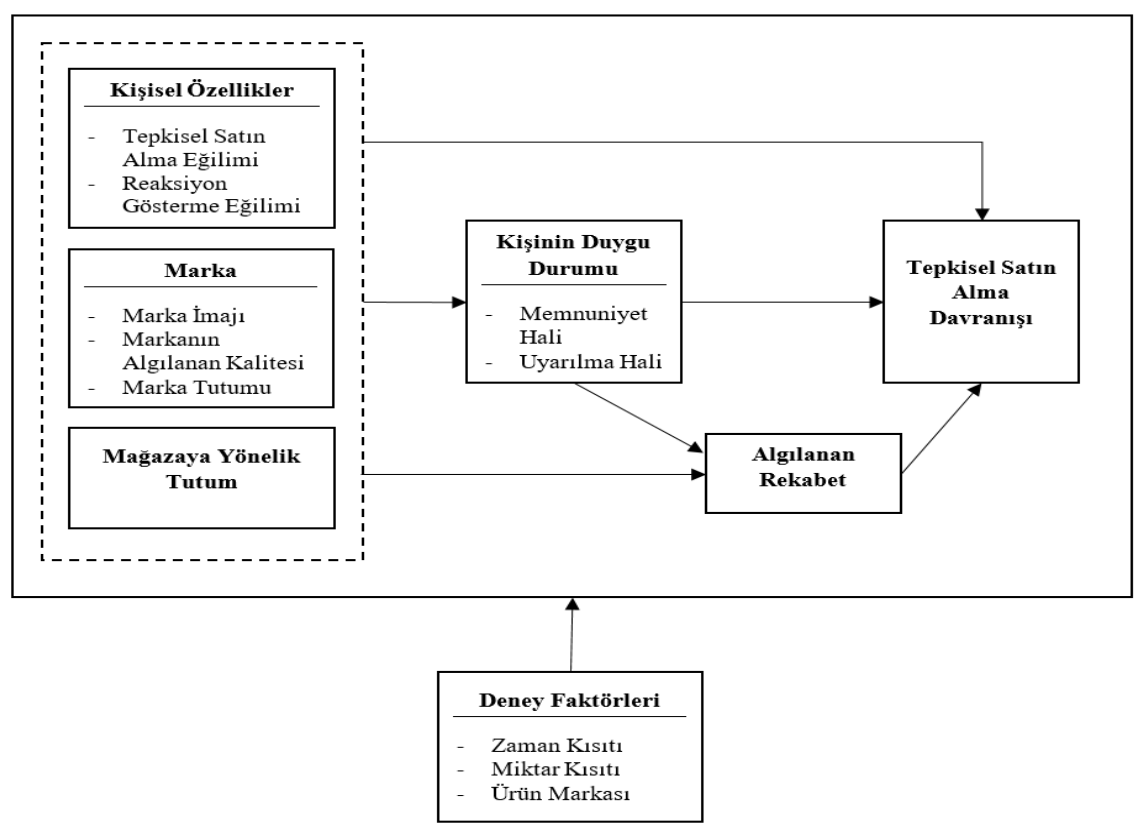

Şekil 2.: Araştırmanın Kavramsal Modeli

\section{Veri Toplama Yöntemi ve Aracı}

\section{Deneysel Tasarım, Uygulama ve Veri Toplama Süreci}

Çalışma sürecinde araştırma değişkenleri bağlamında, deneysel tasarım yöntemi ile araştırma sorusunun sorgulanması ve yanıtlanması şeklinde hareket edilmiştir (Klein, 2011:8; Montgomery, 2010:1; Malhotra, 2010:228; Hair vd., 2010:443). Farklı düzeylerdeki deney değişkenleriyle çalışılması hedeflendiğinden, böylesi koşullarda başarılı sonuç edinilen 'Faktöryel Tasarım' tekniğiyle deneysel süreç yapılandırılmıştır (Hair, 2010:264; Montgomery, 2010:162). 2x2x2 Faktöryel Tasarım ile düzenlenmiş uygulamalarda üç deney değişkeni ve her bir deney değişkeninin iki seviyesi ile çalışılmıştır. Şekil 3 'te görülmekte olan deney tasarım sürecinde, olağan alışverişlerindeki müşterilerle, market alışverişi ortamında deney koşulları tasarlanmış ve uygulanmıştır. Deney koşullarını deneyimleyerek ürün satın alan ve çalışmaya katılımı kabul eden tüketicilerle yüz yüze anket yöntemi ile veri toplanılmıştır.
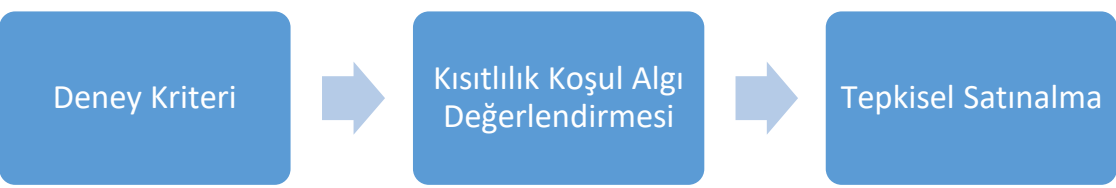

\section{Şekil 3: Deney Süreç Akış1}

Araştırmanın ana kütlesi, R ilinde yaşayan ve süpermarket alışverişi gerçekleştiren, 18 yaşın üstündeki tüketicileri kapsamaktadır. Deneysel araştırma, günlük market alışveriş ortamındaki müşterilerle yapıldığından dolayı kolayda örnekleme yöntemiyle çalışılmıştır (Malhotra, 2010:362). Deneysel uygulamalar bütününde katılımcıların her bir deney grubuna eşit miktarda dağılımına dikkat edilmiştir. Her grup için analizlerin verimliliği açısından asgari 120 kişi olacak şekilde, toplamda 960 geçerli veri ile çalışılmıştır.

Sahada gerçekleşen deneysel çalışma, 2000 yılından bu yana dört şube ile Türkiye Cumhuriyeti R ili merkezinde hizmet veren bir hipermarket zinciri olan K Hipermarket'in şehrin merkezindeki şubesinde uygulanmıştır. 


\section{F. İ. Konyalıŏlu - A. Şekerkaya 12/4 (2020) 3518-3538}

Çalışma mağaza ortamında, alışverişteki müşterilerle, gündelik ve olağan süpermarket alışveriş saatlerinde yapılmıştır. Mağazadaki alışverişleri sonunda, ödeme aşamasındaki müşterilere ankete katılım durumları sorulmuştur. Böylelikle, geleneksel perakendecilik ortamı müşterilerini içeren ana kütleyi temsil eden örneklemi oluşturan katılımcılarla çalışılmıştır.

Çalışmada tüketicilerin tepkisel satın alma eğilimlerini ölçmek amacıyla Rook ve Fisher (1995:308) tarafından geliştirilen dokuz ifadeli ‘Tepkisel Satın Alma’ ölçeği çalışma ortamına uyarlanarak kullanılmıştır. Ölçek tepkisel satın alma eğilimini hem bilişsel hem de eyleme dair yanlarıyla ölçebilmektedir. Miktar ve satın alma karar zamanı kısıtlılık ölçümü üç farklı ölçeğin birleştirilmesi ile gerçekleşmiştir (Aggarwal vd., 2011:27; Byun ve Sternquist, 2012:232, 2011:189; Byun ,2006:81; Kim, 2014:29). Satıştaki ürün miktarı ve satın alma karar süresine dair kısıtlılığa yönelik ölçümleme yapılmıştır. Aggarwal'ın ölçeğiyle kısıtlılık koşulunda diğer tüketicilerle birbirleri arasında olabilecek rekabet algısı incelenmiştir. Byun ve Sternquist ölçeğiyle kısıtlılık koşullarının algılaması ve bu algılamayla hedef ürünü satın alma davranışına dair ölçme yapılmıştır. Araştırmadaki tüketicilerdeki tepkisel satın alma davranışına dayanak şeklinde incelenen psikolojik reaksiyon sergilenmesi bahsi modelin kritik ve teorik boyutundaki değişkenidir. Brehm'in Psikolojik Reaksiyon teorisine yönelik olarak tepkisel şekilde satın alım gerçekleştiren tüketicilerin, psikolojik reaksiyon sergileyebilmelerini ölçmek üzere Hong-Faedd'in 1996'da geliştirdiği ölçek kullanılmıştır. Ölçek (Hong ve Faedda, 1996:178) psikolojik reaksiyonu hem bilişsel hem de eyleme dair yanlarıyla ölçmektedir. Tepkisel satın alma davranışına etkileri sebebiyle hem uyarılma hem de memnuniyet duygu durumlarına araştırma modelinde önemli yer verilmiştir. Çalışmaya katılan tüketicilerin satın alma gerçekleştirdikleri sıradaki duygu durum ölçümlenmesi amacıyla, Kacen ve Lee'nin 2011 yılında geliştirdiği, 'Duygu Durum Ölçeği' kullanılmıştır. Deney değişkenlerinden biri olan ürün markası üç ana boyutta incelenmiştir. Bunlar tüketicideki ürün markası imajı, marka kalite algısı ve markaya yönelik tüketici tutumları şeklindedir. Bahsi olan üç boyut Low ve Lamb (2000)'ın geliştirdikleri ölçeğin araştırmanın ürünü, ortamı ve koşullarına uygun on bir ifadesi alınarak incelenmiştir. Çalışmaya katılan tüketicilerin alışveriş ortamına yönelik alg1sı ve tutumunu ölçmek için birden fazla ölçeğe ait ifadeler birleştirilerek kullanılmıştır. Bunlar, Sirohi vd. (1998) Ürün Kalitesi Algısı ile Bolton ve Drew (1991); Dodds vd. (1991); Grewal vd. (1998), 'Değer Alg1sı' ölçeğinden gelen toplamdaki altı ifadedir.

Araştırmanın veri toplama sürecinde her bir deney grubu için ayrı çalışma haftası belirlenmiştir. Her gruptan ayrı bir haftada olacak şekilde, sekiz haftalık sürede veriler toplanmıştır. Araştırmanın makro boyuttaki etkilerine dair incelemeler de gerçekleşmiştir. Deneysel çalışma için tercih edilen ürün markalarının uygulama öncesinde ve sürecindeki satış verileri değerlendirilmiştir. X markalı ürünün uygulamanın öncesindeki ayda satıldığından 2,31 (\%230) katı daha fazla satış gerçekleşmiştir. Uygulamanın sonlanması akabindeki aylık satışlar 3 katı azalmıştır. Bir sene önceki eş dönemden oransal olarak \%60 daha fazla $X$ markalı ürün satılmış olduğu görülmüştür. Y markalı ürün uygulama öncesindeki ayda satıldığından 6,7(\%670) katı daha fazla satış gerçekleşmiştir. Uygulamanın sonlanması akabindeki aylık satışlar 12 katı azalmıştır. Bir sene önceki eş dönemden oransal olarak \%80 daha fazla Y markalı ürün satılmış olduğu görülmüştür. İki senelik satış verilerine bakıldığında hem $X$ hem de $Y$ markalı çalışılan ürünlerin en yüksek orandaki ürün satış miktarlarının uygulamaların gerçekleştiği dönemde olduğu görülmüştür.

Çalışmada tertip edilmiş olan deney gruplarına göre deney değişkenlerinin dağılımı Tablo 1'de yer almaktadır. 
Tablo 1: Deney Grupları

\begin{tabular}{|l|l|l|l|l|}
\hline \multirow{2}{*}{ Deney Grubu } & \multicolumn{2}{|l|}{ Deney Değişkenleri } & \multirow{2}{*}{ Toplam } \\
\cline { 2 - 5 } & $\begin{array}{l}\text { Miktar } \\
\text { Kisıtı }\end{array}$ & $\begin{array}{l}\text { Zaman } \\
\text { Kisıtı }\end{array}$ & Marka & \\
\hline A & Var & Var & X & 120 \\
\hline B & Var & Yok & Y & 120 \\
\hline C & Var & Yok & X & 120 \\
\hline D & Yok & Var & Y & 120 \\
\hline E & Var & Var & Y & 120 \\
\hline F & Yok & Var & X & 120 \\
\hline G & Yok & Yok & Y & 120 \\
\hline H & Yok & Yok & X & 120 \\
\hline Toplam & & & 960 \\
\hline
\end{tabular}

Haftalara göre deneysel koşulların atanması $\mathrm{K}$ hipermarketin çalışma düzeni, iş akışı ve verimliliklerine olumsuz etkisi olmayacak şekilde, işletme ile yapılan görüşmelerde belirlendiği şekilde olmuştur. Tepkisel olarak satışı incelenen ürün gramajı, güdüleyici ve düzenleyici olarak belirlenen indirim uygulamasını anlamlı kılabilmesi amacıyla, K Market yönetimi ile kararlaştırılmış olan, en yüksek gramajlı X 750 gr ve Y 1000 gr dır. Sürecin uygulandığı marketin mağaza ortam görünümü Şekil 4 'de yer almaktadır.

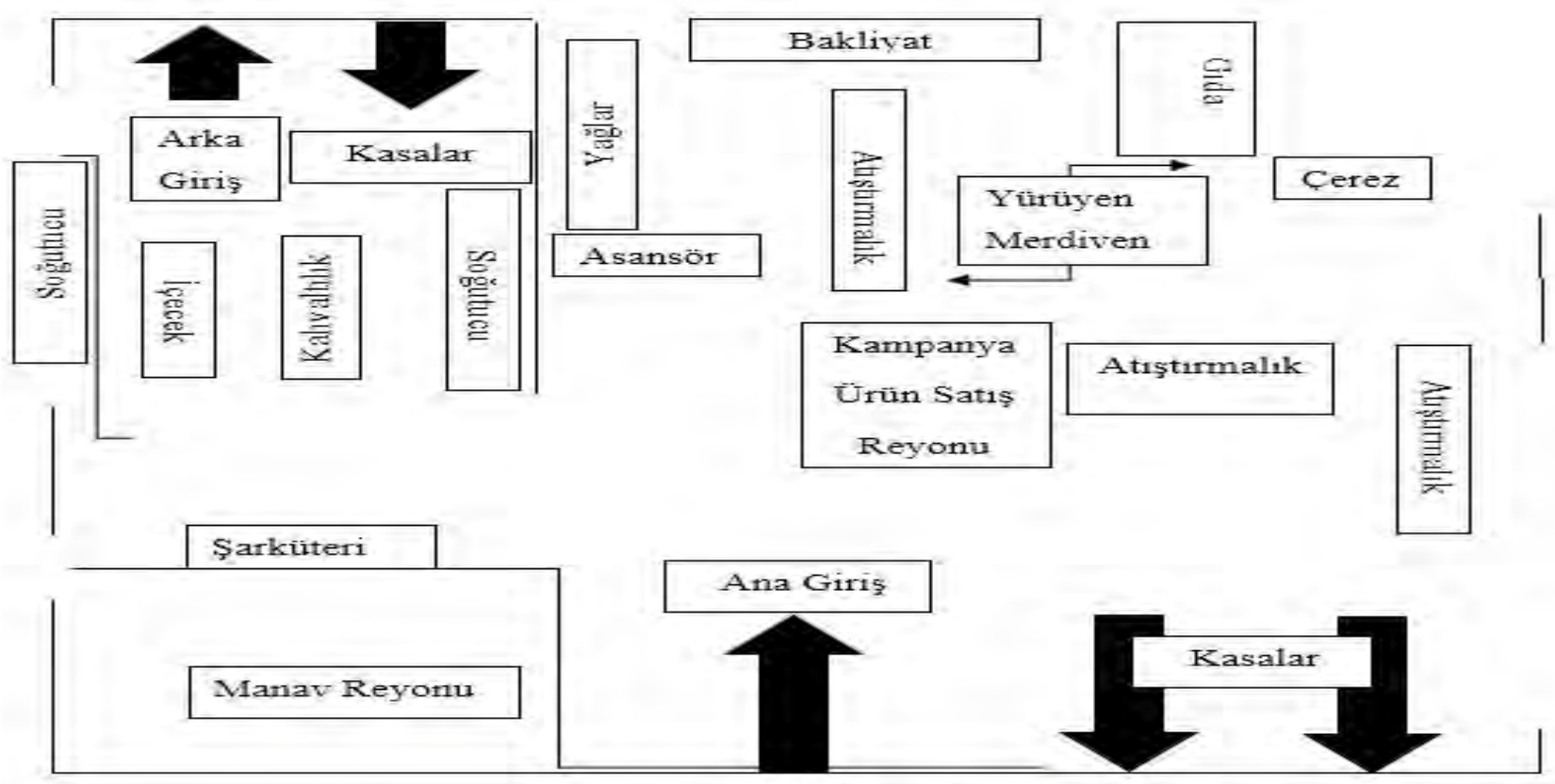

Şekil 4: Mağaza Ortamı

Sekiz hafta süre ile her bir deney koşulu satın alma davranışını güdüleyici ve düzenleyici fiyat indirimi ile mağazada uygulanmiştır. 


\section{Bulgular}

\section{Sosyo-Demografik Bilgiler}

Çalışma katılımcılarının \%78'i nakit olarak ürün satın almışlardır. Çalışılan ürün gramajı (aile boyu) en sık satın alınan ölçüdedir. Daha çok orta seviye sosyoekonomik kesim ürünü satın almıştır. En çok ev kadınları ürünü satın alanlardır. Ürünü satın alanların eğitim seviyesi yüksek değildir. \%80 oranında çocuklu, özellikle de iki ve üç çocuklu aileler ürünü satın almıştır. Katılımcıların \%82'si evlidir.

Katılımcıların \%60'ı kakaolu fındık kreması ürününü ayda birkaç defa satın aldıklarını belirtmişlerdir. Katılımcıların \%68'i marketten haftada bir veya birkaç defa alışveriş yaptıklarını söylemişlerdir. Katılımcıların olağan hayat akışında \%44'ü X, \%42'si de Y markalı kakaolu fındık kreması ürünü satın aldıklarını ifade etmişlerdir. En sık şekilde 50 yaşındaki kişilerin ürünü satın aldığı ve katılımcıların yaş ortalamalarının 41 olduğu görülmüştür. Bu tüketicilerin \%52'si kadın, \%84' ü R kentlidir. Deneysel uygulamalara katılmış olan tüketicilerin \%90 ‘nın sürekli olarak kakaolu fındık kreması ürünü satın aldığı, \%50'sinin beraberlerindeki kişiyle alışverişte olduğu görülmüştür. Beraberlerindeki kişilerin \%50'sinin kadın olduğu, beraber alışveriş yapılan kişinin katılımcının evladı ve akrabası olduğu, katılımcıların \%95'inin ailecek ürün tüketimi için ürünü satın aldığı tespit edilmiştir.

\section{Araştırma Ölçeklerinin Geçerliliği ve Güvenirliliği}

Araştırma değişkenlerini ölçmek için kullanılan araştırma ölçeklerinin güvenirliklerinin ölçülmesi için içsel tutarlılıklarını sınıyor olan Cronbach Alfa değerleri hesaplanmıştır. Gözlenen değerlerin örtülü faktörlerle ilişkisinin incelenmesi için güvenilirlilik testi yapılmıştır. Ölçeklerin yapısal geçerliliklerinin ölçülmeleri Açımlayıcı Faktör Analizi ve Doğrulayıcı Faktör Analizi ile gerçekleştirilmiştir. Her bir ölçeğin yapısal geçerliliğinin değerlendirilmesi ilgili hipotezlerin ölçümlendiği ifadelerin faktör ağırlıklarının standartlaştırılmış doğrulayıcı faktör analiziyle yapılmıştır. Hipotez yapısına dair ifadelerin faktör ağırlığının kabul edilebilir yapısal geçerlilik için 0,70'1 aşması ön görülmüştür. Literatürde kabul gören asgari ölçütler (Hair vd., 2010) göz önünde bulundurularak araştırma ölçeklerinin geçerliği ve güvenirliğinin kabul edilebilir olduğu değerlendirilmiş ve bu bağlamda oluşturulan değişkenler kullanılarak sonraki analizler gerçekleştirilmiştir.

\section{Deney Gruplarının Eşdeğerliği}

Araştırmada yer alan farklı deney gruplarının sosyo-demografik özellikler açısından benzerliklerinin sağlanmasının yanı sıra, araştırma kapsamındaki ürün grubuna (kakaolu fındık kreması) yönelik ilgilenimlerinin de benzer olması planlanmıştır. Bu amaçla ürün ilgilenimi değişkeni araştırma kapsamına dahil edilmiş ve her bir deney grubundaki katılımcının ürüne yönelik ilgilenimleri ölçülmüştür.

Deney gruplarındaki katılımcıların ürün ilgilenimlerinin genel olarak yüksek seviyede olduğu görülmüştür. Yapılan tek yönlü varyans analiz sonucunda deney grupları arasında \%95 güven seviyesinde anlamlı farklılık olmadığı bulunmuştur ( $\mathrm{p}>0.05)$. Buna göre sekiz deney grubunun her birinde yer alan katılımcıların ürün ilgilenimlerinin benzer olduğu sonucuna ulaşılmış ve bu açıdan da deney gruplarının eşdeğerliğinin sağlandığı değerlendirilmiştir.

\section{Deney Değişkenlerine Göre Farklılıkların Belirlenmesi}

Her deney grubundaki tüketicilerin tepkisel satın alma davranışları, algılanan rekabet, uyarılma ve memnuniyet değişkenlerinin ortalamalarındaki anlamlı farklılıklar incelenmiştir. Fark analizi için Faktöryel Anova yöntemi kullanılmıştır. Analizlerle ulaşılan anlamlı sonuçlar özet olarak Tablo 2'de ifade edilmiştir. 
F. İ. Konyalıŏglu - A. Şekerkaya 12/4 (2020) 3518-3538

Tablo 2: Deney Değişkenlerine Göre Farklılıklar

\begin{tabular}{|c|c|c|c|c|}
\hline \multicolumn{5}{|c|}{ Tepkisel Satın Alma Davranışının Deney Değişkenlerine Göre Farklılıklarının Belirlenmesi } \\
\hline Etkiler & $\begin{array}{ll}\text { Type III Kareler } \\
\text { Toplamı }\end{array}$ & Ort. Karesi & $\mathrm{F}(1,952)$ & P Değeri \\
\hline Marka & ,301 & ,301 & 5,015 & , $025^{*}$ \\
\hline Miktar Kısıtlılığ1 & ,782 & 782 & 13,028 & , $000^{*}$ \\
\hline \multicolumn{5}{|c|}{ Algılanan Rekabetin Deney Değişkenlerine Göre Farklılıklarının Belirlenmesi } \\
\hline Zaman Kisitlılı̆ğ1 & 421,019 & 421,019 & 1865,494 & , $000^{*}$ \\
\hline Miktar Kısitlılı̆̆1 & 1363,863 & 1363,863 & 6107,934 & , $000^{*}$ \\
\hline $\begin{array}{l}\text { Marka*Miktar } \\
\text { Kisitllılığ1 }\end{array}$ & 1,187 & 1,187 & 5,314 & , $021^{*}$ \\
\hline $\begin{array}{l}\text { Zaman Kisitll1lığ }{ }^{*} \\
\text { Miktar Kisttll1ığ }\end{array}$ & 435,041 & 435,041 & 1948,290 &, $000^{*}$ \\
\hline \multicolumn{5}{|c|}{ Tüketicilerin Duygu Durumunun (Memnuniyet) Deney Değişkenlerine Göre Farklılıklarının Belirlenmesi } \\
\hline $\begin{array}{l}\text { Marka*Zaman } \\
\text { Kisitlllığ1 }\end{array}$ & 1,313 & 1,313 & 4,518 & , $034^{*}$ \\
\hline $\begin{array}{l}\text { Marka*Miktar } \\
\text { Kisttllığg1 }\end{array}$ & 1,465 & 1,465 & 5,042 &, $025^{*}$ \\
\hline $\begin{array}{l}\text { Zaman Kisitll1lığ }{ }^{*} \\
\text { Miktar Kisitll1ığ }\end{array}$ & 2,109 & 2,109 & 7,260 & , $007^{*}$ \\
\hline \multicolumn{5}{|c|}{ a. R Squared $=, 021$ (Adjusted R Squared $=, 014)$} \\
\hline \multicolumn{5}{|c|}{ Kişinin Duygu Durumunun (Uyarılma) Deney Değişkenlerine Göre Farklılıklarının Belirlenmesi } \\
\hline Zaman Kisitlılığ1 & 1,504 & 1,504 & 4,057 &, $044^{*}$ \\
\hline $\begin{array}{l}\text { Marka*Zaman } \\
\text { Kisitlıllı̆ } 1\end{array}$ & 3,384 & 3,384 & 9,127 &, $003^{*}$ \\
\hline $\begin{array}{l}\text { Zaman Kisitll1lı̆g }{ }^{*} \\
\text { Miktar Kisttll1ığ }\end{array}$ & 2,604 & 2,604 & 7,023 &, $008^{*}$ \\
\hline 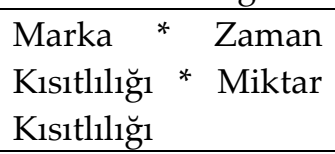 & 3,750 & 3,750 & 10,113 &, $002^{*}$ \\
\hline a. R Squared $=, 035$ & djusted R Squared $=$, & & & \\
\hline
\end{tabular}

\section{Deney Değişkenlerine Göre Tepkisel Satın Alma Davranışındaki Farklılıklar}

Deneysel uygulama bünyesinde gelişen tepkisel satın alımların deney değişkenlerinden markaya ve ürün miktar kısıtlılığına göre farklılaştığı söylenebilmektedir $[F 1(1,952)=5,015, p<0.05 ; F 3(1,952)=13,028, p<0.05]$. Zaman kısıtlılığ 1 açısından da anlamlı farklılık olamamaktadır $[F 4(1,952)=0,56, p>0.05 ; F 7(1,952)=0,56, p>0.05 ; F 5(1$, $952)=0,367, p>0.05 ; F 6(1,952)=1,533, p>0.05 ; F 2(1,952)=1,533, p>0.05]$. Marka değişkenine göre tüketicilerin \%25 fiyat indiriminden istifade ederek ürün miktar kısıtlılı̆̆ı olmayan koşulda ve $\mathrm{Y}$ markalı ürünlere dair farklılaşan anlamlı şekilde tepkisel satın alma yaptıkları görülmektedir.

\section{Deney Değişkenlerine Göre Algılanan Rekabet Farklılıkları}

\%25 fiyat indirimini ürün miktar $[F 3(1,952)=6107,934, p<0.05]$ ve zaman k1sitlllı̆̆ $[F 2(1,952)=1885,494, p<0.05]$ koşullarını deneyimleyen tüketicilerde algılanan rekabet farklılaşmasının anlamlı olduğu ifade edilebilir. Deney değişkenlerinden ürün markası ile ürün miktar kısıtlılığının birlikte incelendiği deney koşulunda tüketicilerin diğer tüketicilerle aralarında rekabet algilamalarının anlamlı farklılaştığ $1[F 5(1,952)=5,314, p<0.05]$ belirtilebilir. Her iki kısıtlılık koşulunun eş zamanlı tatbik edildiği koşulda da tüketicilerin diğer tüketicilerle aralarında rekabet algılamalarının anlamlı farklılaştığ $[F 6(1,952)=1948,290, p<0.05]$ işaret edilebilir. 


\section{F. İ. Konyalıŏlu - A. Şekerkaya 12/4 (2020) 3518-3538}

Marka deney değişkeninin \%25 fiyat indirimi ile sadece satın alma zaman kısıtllı̆̆ğ1 ve her iki kısıtlılık koşuluyla da eş zamanlı tatbik edilmesini deneyimleyen tüketicilerin diğer tüketicilerle aralarında rekabet algılamalarının anlamlı farklılaşmadığına da değinilebilir $[F 1(1,952)=0,35, p>0.05 ; F 4(1,952)=0,490, p>0.05 ; F 7(1,952)=2,743$, $p>0.05]$.

\section{Deney Değişkenlerine Göre Tüketicilerin Memnuniyet Duygu Durumlarının Farklılıkları}

Eş zamanlı olarak iki kısıtlılık koşulunda fiyat indiriminin tatbik edilmesi tüketicilerin memnuniyet duygu durumlarında anlamlı farklılığı getirebilmektedir $[F 6(1,952)=7,260, p<0.05]$. Ürün miktar kısıtlılığı ile marka $[F 5(1,952)=5,042, p<0.05]$ ve zaman kısıtlılığı ile marka $[F 4(1,952)=4,518, p<0.05]$ değişkenlerinin birlikte deneysel uygulamaya alındığı koşullarda da tüketicilerin memnuniyet duygu durumlarında anlamlı farklılaşma görülebilmiştir.

Deney değişkenlerinin her birinin tek ve üçü birlikte tatbik edilmesi koşullarında tüketicilerin memnuniyet duygu durumlarına göre anlamlı farklılaşma olmadığı söylenebilir $[F 1(1,952)=0,861, p>0.05 ; F 3(1,952)=2,241, p>0.05$; $F 2(1,952)=0,516, p>0.05 ; F 7(1,952)=0,108, p>0.05]$.

Herhangi bir kısıtlılık koşulu deneyimlemeyen tüketicilerin en yüksek memnuniyet duygu durumu barındırarak diğer deneysel koşullar deneyimlemişlerden anlamlı farklılaştı̆̆ ifade edilebilir.

Tüketiciler $\mathrm{Y}$ markalı ürün için zaman kısıtlılığı yaşamadıkları ve $\mathrm{X}$ markalı ürün içinse yaşadıklarında memnuniyet duygu durumları diğer koşullardan nispeten en yüksek düzeyle anlamlı farklılaşabilmektedir. Tüketiciler X markalı ürün için miktar kısıtlılı̆̆ı ile karşılaşmadıkları ve Y markalı ürün içinse karşılaştıklarında memnuniyet duygu durumları diğer koşullardan nispeten en yüksek düzeyle anlamlı farklılaşmıştır.

\section{Deney Değişkenlerine Göre Tüketicilerin Uyarılma Duygu Durumlarının Farklılıkları}

Miktar ve zaman kısıtlılığı ile marka deney değişkenlerinin üçünü birlikte eş koşulda deneyimleyen tüketicilerin uyarılma duygu durumunda nispeten en anlamlı düzeyde farklılaşma $[F 7(1,952)=10,113, p<0.05]$ gösterdiği belirtilebilir.

Tüketicilerin markaya göre zaman kısıtlılığını $[F 4(1,952)=9,127, p<0.05]$ ve her iki kısıtlılığın birlikte tatbik edilmesi durumlarını deneyimlemesi uyarılma duygu durumunun diğer koşullarla anlamlı farklılaşmayı [F6 (1, $952)=7,023, p<0.05$ ] geliş̧tirdiği söylenebilir. Sadece zaman kısıtlılığı tatbik edilen deney koşulunda da uyarılma duygu durumunun diğer koşullara göre anlamlı farklılaştığ1 $[F 2(1,952)=4,057, p<0.05]$ ifade edilebilir.

Deney değişkenlerinden hem markanın hem de ürün miktar kısıtlılığının tek tek ve marka ile miktar kısıtlılığının eş zamanlı tatbik edilmesi koşullarında tüketicilerin uyarılma duygu durumunun anlamlı farklılaşmadığı söylenebilir $[F 1(1,952)=0,25, p>0.05 ; F 3(1,952)=2,202, p>0.05 ; F 5(1,952)=1,486, p>0.05]$.

Deney değişkenlerinden marka ile zaman kısıtlılığının birlikte uygulanması durumunda $X$ markalı ürüne fiyat indiriminin tüketicilerde en yüksek düzeyde uyarılma duygu durumunun gelişmesine sebep olduğu işaret edilebilir. Y markalı ürün için tüketicilerde en düşük uyarılma duygu durumunun tecrübe edilişi fiyat indiriminin sadece zaman kısıtlılı̆̆ ile tatbik edilmesi halinde görülebilmektedir.

\section{Yol Analizi Sonuçları}

Faktör Analizleri sonucunda nihai yapılarına karar verilen araştırma değişkenleri açısından araştırma modelindeki etkilerin ve araştırma hipotezlerinin değerlendirilmesi amacıyla gözlenen değişkenlerle yol analizi uygulanmıştır. Analiz uygulanmadan önce faktör analizlerinden elde edilen faktör yapıları temel alınmış ve bu faktörler içerisindeki ifadelerin ortalamaları alınarak analizde kullanılan değişkenler oluşturulmuştur.

Yapılan analizler sonucunda 'yol şemaları' elde edilmiştir. İncelenen yol şemaları üzerinden analiz sonuçları yorumlanmış ve ilişkilerin değerlendirilmesi yapılmıştır (Kline,2011:10). Bu araştırma kapsamındaki analiz sonuçlarını içeren Yol Diagramı Şekil 5'te görülmektedir. Her bir yolun anlamlılı̆̆ının değerlendirilmesi için $t$ değerleri incelenmiştir. Anlamlı gelen $t$ değerleri $(p<0,05)$ işaret edilmiştir. Yol şemalarında da anlamlı olan ilişkiler (\%95 güvenilirlik sınırları içinde) ifade edilmiştir (Kline,2011:15). Yol kat sayıları incelendiğinde 0,10 ve 


\section{F. İ. Konyalıŏlu - A. Şekerkaya 12/4 (2020) 3518-3538}

altındaki ilişkiler düşük, 0,30 civarındaki ilişkiler orta ve 0,50 ile üzerindeki etkilerse yüksek etkili olarak değerlendirilmiştir.

Yol analiz sonuçları ile kabul edilen hipotezler ortaya konmaktadır. Tüketicilerdeki memnuniyet duygu durumlarının(H6a), ürün markası imajının(H4c) ve satın alma tepkiselliğinin eyleme dair yanının(H4a) tepkisel satın alma davranışlarına etkisi olduğu görülmüştür. Tüketicilerdeki tepkiselliğin bilişsel tarafı(H3a) eş koşulları paylaştıkları diğer tüketicilerle aralarında rekabet algılamalarıyla tepkisel satın alma davranışından kaçınmalarına sebep olabilmektedir. Tüketiciler psikolojik reaksiyon sergileme eğilimlerinin hem bilişsel hem de eyleme dair yanlarının etkisiyle(H3b) başkalarıyla aralarında rekabet algılayarak tepkisel satın alma davranışı sergilemişlerdir.

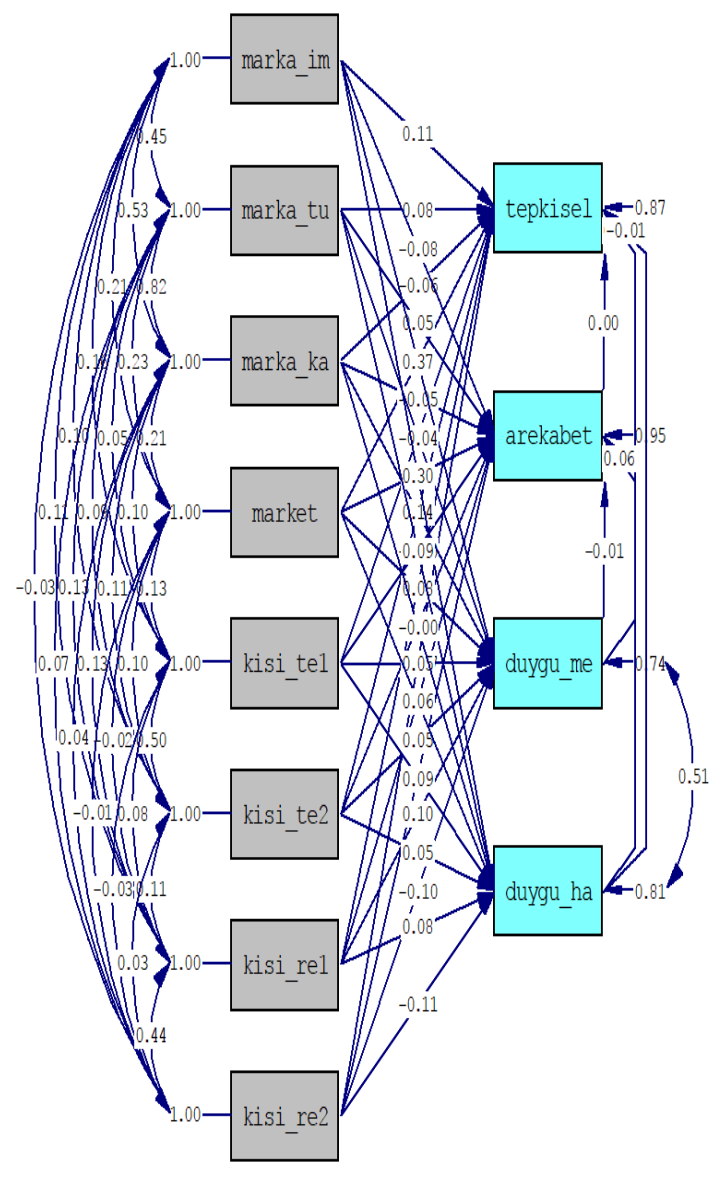

Chi-Square $=0.00, \mathrm{df}=0, \mathrm{P}-\mathrm{value}=1.00000, \mathrm{RMSEA}=0.000$

\section{Şekil 5: Analiz Sonuçlarını İçeren Yol Diagramı}

Tüketicilerdeki marka imaj1(H1c) hem memnuniyet hem de uyarılma(H2c) duygu durumlarına yüksek etki yaparak tepkisel satın alma davranışları gerçekleşmiştir. Her iki duygu duruma da etkisi olan diğer değişkenler; mağazaya yönelik tutum(H1f, H2f) ile psikolojik reaksiyon sergileme eğilimlerinin bilişsel(H1b, H2b) yanlarıdır. Memnuniyet duygu durumlarına etki eden marka kalite algısı(H1e) ile uyarılma duygu durumlarına(H2a) satın alma tepkiselliğinin eyleme dair tarafının etkisiyle tepkisel satın alma davranışları yaşanmıştır. Psikolojik reaksiyon sergileme eğilimlerinin eyleme dair yanlarınınsa hem memnuniyet hem de uyarılma duygu durumlara(H1b, H2b) etkisi tepkisel satın alma davranışından nispeten kaçınılmasına sebep olmuştur.

\section{Deney Grupları Açısından Etki Farklılıklarının Değerlendirilmesi}

Farklılıkların değerlendirilmesinde öncelikle her bir grup kendi içerisinde gözlenen değişkenlerle yol analizine tabi tutulmuş ve etki değerleri hesaplanmıştır. Ayrıca gruplar arası farklılıkları tespit etmek açısından da $\mathrm{Z}$ fark 


\section{F. İ. Konyalıŏlu - A. Şekerkaya 12/4 (2020) 3518-3538}

testi yaklaşımından yararlanılmıştır (Malhotra, 2010:515). Deney koşulları tatbik edilerek çalışılmış olan gruplar hem kendi grup bünyelerinde hem de birbirlerine mukayeseli şekilde incelenmişlerdir. Gruplara dair değişkenler arasındaki yol analizi sırasında edinilmiş standartlaştırılmamış etki/regresyon katsayıları $(b)$, hata varyansları $(S E)$, standartlaştırılmış regresyon katsayıları $(\beta)$ ve görülen etkilerin anlamlılığına ilişkin $t$ değerleri hesaplanmıştır.

Gruplar arası farklılık görülmese de gruplardaki eş değişkenler arası gözlenen anlamlı etkiler de vardır. Deney grupları arasında mukayeseli olarak bu etkilerin incelemesi yapılmıştır. H7 hipotezinin kabul edildiği görülmüştür.

Markaya (X) göre her iki kısıtlılık koşulunun ve sadece miktar kısıtlılı̆̆ının yaşandığ 1 iki grup arasında mukayeseli etki farkları değerlendirilmesi yapılmıştır. Tüketicilerdeki ürün markası tutumlarının tepkisel satın alma davranışlarına anlamlı ters yönlü etki farkı olduğu görülmektedir. Tüketicilerin psikolojik reaksiyon sergileyebilme eğilimlerinin bilişsel yanının başkalarıyla aralarında rekabet algılamalarına anlamlı ters yönlü etki farkı vardır. Markası kalite algısının memnuniyet duygu durumlarına anlamlı ters yönlü etki farkı olmuştur. Tüketicilerdeki marka kalite algısının ve tepkisel satın alma eğilimlerinin bilişsel yanının uyarılma duygu durumlarına anlamlı ters yönlü etki farkları görülmüştür.

Markaya (Y) göre her iki kısıtlılık koşulunun ve sadece miktar kısıtlılığının yaşandığ 1 iki grup arasında mukayeseli etki farkları değerlendirilmesi yapılmıştır. Tüketicilerin başkalarıyla aralarında rekabet algılamalarının tepkisel satın alma davranışlarına anlamlı ters yönlü etki farkı görülmüştür. Tepkisel satın alma davranışlarına marka tutumlarının olumlu ve kalite algılarının da ters yönlü anlamlı etki farkları olmuştur. Psikolojik reaksiyon sergileme eğilimlerinin eylem yanının başkalarıyla aralarında rekabet algılamalarına anlamlı ters yönlü etki farkı vardir.

Markaya (X) göre her iki kısıtlılık koşulunun ve sadece zaman kısıtlılı̆̆ının yaşandığı iki grup arasında mukayeseli etki farkları değerlendirilmesi yapılmıştır. Tüketicilerin başkalarıyla aralarında rekabet algılamalarının tepkisel satın alma davranışlarına anlamlı etki farkı olmuştur. Tüketicilerin başkalarıyla aralarında rekabet algılamalarına marka kalite algılarının ters yönlü ve psikolojik reaksiyon sergileme eğilimlerinin eylem yanlarının anlamlı olumlu etki farkları olmuştur. Marka kalite algısının memnuniyet duygu durumlarına anlamlı ters yönlü etki farkı vardır. Uyarılma duygu durumlarına marka tutumlarının olumlu ve kalite algılarının ters yönlü anlamlı etki farkları görülmüştür.

Markaya (Y) göre her iki kısıtlılık koşulunun ve sadece zaman kısıtlılığının yaşandığı iki grup arasında mukayeseli etki farkları değerlendirilmesi yapılmıştır. Tüketicilerdeki marka kalite algısının tepkisel satın alma davranışlarına anlamlı ters yönlü etki farkı vardır. Mağazaya yönelik tutumların memnuniyet duygu durumlarına anlamlı ters yönlü etki farkı olmuştur. Marka kalite algısının uyarılma duygu durumlarına anlamlı olumlu etki farkı görülmüştür.

Markaya (X) göre her iki kısıtlılık koşulunun ve kısıtlılık uygulanmayan satışın yaşandığı iki grup arasında mukayeseli etki farkları değerlendirilmesi yapılmıştır. Tüketicilerin başkalarıyla aralarında rekabet algılamalarının tepkisel satın alma davranışlarına anlamlı ve önemli etki farkı görülmüştür. Tepkisel satın alımlara tepkisel satın alma eğilimlerinin eylem yanının olumlu ve psikolojik reaksiyon sergileyebilme eğilimlerinin eylem yanının anlamlı ters yönlü etki farkları vardır. Algılanan rekabete uyarılma duygu durumunun olumlu, marka imajının önemli ve olumlu, psikolojik reaksiyon sergileyebilme eğilimlerinin bilişsel yanının anlamlı ters yönlü etki farkı olmuştur.

Markaya (Y) göre her iki kısıtlılık koşulunun ve kısıtlılık uygulanmayan satışın yaşandığı iki grup arasında mukayeseli etki farkları değerlendirilmesi yapılmıştır. Tüketicilerin tepkisel satın alma eğilimlerinin eylem yanının tepkisel satın alma davranışlarına anlamlı olumlu etki farkı olmuştur. Tepkisel satın alma eğilimlerinin bilişsel yanının başkalarıyla aralarında rekabet algılamalarına anlamlı olumlu etki farkı görülmüştür. Marka imajının memnuniyet duygu durumlarına anlamlı ters yönlü etki farkı olmuştur. Marka imajının hem uyarılma hem de memnuniyet duygu durumlarına anlamlı ters yönlü etki farkları vardır. Uyarılma duygu durumlarına 


\section{F. İ. Konyalığlu - A. Şekerkaya 12/4 (2020) 3518-3538}

psikolojik reaksiyon sergileyebilme eğilimlerinin bilişsel yanının olumlu ve eyleme dair yanının anlamlı ters yönlü etki farkları olmuştur.

Markaya (X) göre sadece miktar kısıtlılık koşulunun ve kısıtlılık uygulanmayan satışın yaşandığ iki grup arasında mukayeseli etki farkları değerlendirilmesi yapılmıştır. Tüketicilerin tepkisel satın alma davranışlarına başkalarıyla aralarında rekabet algılamaları ile marka tutumunun anlamlı olumlu etki farkları olmuştur. Marka imajının başkalarıyla rekabet algısına önemli anlamlı olumlu etki farkı görülmüştür. Memnuniyet duygu durumlarına marka kalite algısı ile psikolojik reaksiyon sergileyebilme eğilimlerinin bilişsel yanının anlamlı olumlu etki farkları vardır. Uyarılma duygu durumlarına da marka imajının ters yönlü ve marka kalite algısının olumlu anlamlı etki farkları görülmüştür.

Markaya (Y) göre sadece miktar kısıtlılık koşulunun ve kısıtlılık uygulanmayan satışın yaşandığ 1 iki grup arasında mukayeseli etki farkları değerlendirilmesi yapılmıştır. Tüketicilerin başkalarıyla aralarında rekabet algılamalarının tepkisel satın alma davranışlarına anlamlı olumlu ve önemli etki farkı olmuştur. Algılanan rekabete marka tutumunun olumlu, marka kalite algısının ters yönlü ve tepkisel satın alma eğilimlerinin bilişsel yanının anlamlı olumlu ve önemli etki farkı görülmüştür. Memnuniyet duygu durumlarına hem marka imajının hem de tepkisel satın alma eğilimlerinin bilişsel yanının ters yönlü anlamlı etki farkları vardır. Uyarılma duygu durumlarına marka imajının anlamlı ters yönlü etki farkı olmuştur.

Markaya $(X)$ göre sadece zaman kısıtlılık koşulunun ve kısıtlılık uygulanmayan satışın yaşandığı iki grup arasında mukayeseli etki farkları değerlendirilmesi yapılmıştır. Tüketicilerin tepkisel satın alma davranışlarına algılanan rekabetin, marka tutumu ve tepkisel satın alma eğilimlerinin eylem yanının anlamlı olumlu etki farkları olmuştur. Rekabet algılamasına marka imajının olumlu ve psikolojik reaksiyon sergileyebilme eğilimlerinin eylem yanının ters yönlü anlamlı etki farkları vardır. Marka kalite algısının hem memnuniyet (hem de uyarılma duygu durumlarına anlamlı olumlu etki farkları görülmüştür. Uyarılma duygu durumlarına marka imajının ters yönlü anlamlı etki farkı vardır.

Markaya (Y) göre sadece zaman kısıtlılık koşulunun ve kısıtlılık uygulanmayan satışın yaşandığı iki grup arasında mukayeseli etki farkları değerlendirilmesi yapılmıştır. Tüketicilerin tepkisel satın alma eğilimlerinin eylem yanının tepkisel satın alma davranışlarına anlamlı olumlu etki farkı vardır. Bilişsel yanının da rekabet algılamalarına anlamlı olumlu etki farkı görülmüştür. Uyarılma duygu durumlarına marka kalite algısının anlamlı ters yönlü etki farkı olmuştur.

Her iki kısıtlılık koşulunun her iki markaya (X, Y) uygulandığı iki grup arasında mukayeseli etki farkları değerlendirilmesi yapılmıştır. Tüketicilerin tepkisel satın alma davranışlarına mağaza tutumlarının ve psikolojik reaksiyon sergileme eğilimlerinin eylem yanının anlamlı ters yönlü etki farkı olmuştur. Uyarılma duygu durumlarına marka tutumlarının anlamlı olumlu etki farkı vardır.

Her iki markanın (X, Y) sadece miktar kısıtlılık koşulu ile satışının uygulandığı iki grup arasında mukayeseli etki farkları değerlendirilmesi yapılmıştır. Tüketicilerin tepkisel satın almalarına başkalarıyla aralarında algıladıkları rekabet ile marka kalite algısının ters yönlü, marka tutumunun olumlu anlamlı etki farkları görülmüştür. Tepkisel satın alma eğilimlerinin eylem yanının rekabet algılamalarına ters yönlü anlamlı etki farkı olmuştur. Memnuniyet duygu durumlarına marka kalite algısı, imajı ve tepkisel satın alma eğilimlerinin bilişsel yanının anlamlı olumlu etki farkları olmuştur. Uyarılma duygu durumlarına da marka kalite algısı ve psikolojik reaksiyon sergileme eğilimlerinin bilişsel yanının anlamlı olumlu etki farkları vardır.

Her iki markanın (X, Y) sadece zaman kısıtlılık koşulu ile satışının uygulandığı iki grup arasında mukayeseli etki farkları değerlendirilmesi yapılmıştır. Tüketicilerin tepkisel satın almalarına marka tutumlarının olumlu ve kalite algılarının ters yönlü anlamlı etki farkları olmuştur. Memnuniyet ve uyarılma duygu durumlarına marka kalite algılarının olumlu anlamlı etki farkları görülmüştür.

Her iki markanın (X, Y) kısıtlılık uygulanmayan satışının uygulandığı iki grup arasında mukayeseli etki farkları değerlendirilmesi yapılmıştır. Tüketicilerin tepkisel satın alma davranışlarına algıladıkları rekabetin anlamlı etki 


\section{F. İ. Konyalığlu - A. Şekerkaya 12/4 (2020) 3518-3538}

farkı olmuştur. Algılanan rekabete marka imajının ters yönlü ve tepkisellikle satın alma eğilimlerinin bilişsel dair yanının olumlu anlamlı etki farkları vardır.

\section{Sonuç ve Tartışma}

Araştırma modeli ve deney değişkenleri bağlamında, gerçekleşen ölçümlemeler sonucunda, değişkenler arasında etkiler ve deney grupları arasındaki etki farklarının analizi yapılarak çalışma süreci tamamlanmıştır. Markaya göre, kısıtlılık koşullarının tatbik edilmesi ve edilmemesi koşullarında psikolojik reaksiyon ilişkili tepkisel satın alma davranışına etkilerin ve durumlara göre gelişen farklılıkların görülmesi mümkün olmuştur. Tüketicilerdeki tepkisel satın alma davranışı, algılanan rekabet, uyarılma ve memnuniyet duygu durum değişkenlerine göre anlamlı şekilde farklılaşmalar görülmüştür. Tepkisel satın alma davranışının markaya ve ürün miktar kısıtlılığına göre farklılıklar gösterdiği ifade edilebilmektedir. Miktar kısıtlılığının olmadığı durumda miktar kısıtlılığının olduğu duruma göre nispeten daha tepkisel şekilde satın alma yapılmıştır. Değişkenlerden markaya göre tepkisel satın alma davranışı gerçekleşmesinin farklılaştığı görülmüştür. Her iki kısıtlılığın ayrı ve markaya göre sadece miktar kısıtlılığı uygulandığında tüketicilerin başkalarıyla aralarında anlamlı farklılaşmayla rekabet algıladıkları ifade edilebilir. Kısıtlılık koşulları tüketicilerin başkalarıyla aralarında rekabet algılamalarına etki edebilmektedir. Markaya göre her iki kısıtlılık koşulunun birlikte uygulandığı koşulda tüketicilerdeki rekabet algılamasında anlamlı farklılaşma olmamıştır. Marka, miktar ve zaman kısıtlılığının her birinin tek ve üçünün de birlikte tüketiciye sunulduğu koşullarda memnuniyet duygu durumlarına göre anlamlı farklılık görülmemiştir. Hem zaman hem de miktar kısıtlılığı koşullarının tatbik edilmediği durumda tüketiciler memnuniyet duygu durumunun nispeten yüksekliğiyle tepkisel satın alma gerçekleşmiştir. Markaya göre sadece zaman ve sadece miktar kısıtlılığı uygulanan koşullarda tüketicilerin memnuniyet duygu durumlarının yüksekliğiyle psikolojik reaksiyon şeklinde tepkisel satın alma yapabildikleri görülmüştür. Markaya göre sadece zaman kısıtlılı̆̆ ve her iki kısıtlılığın eş uygulandığı durumda yüksek düzeyde uyarılma ile tepkisel satın alma yaparak anlamlı farklılık olmuştur.

Marka imajının hem memnuniyet hem de uyarılma duygu durumuna etkisi özellikle dikkat çekicidir. Kısıtlılık olmayan koşullarda marka imajının bu duygu durumlara en yüksek düzeyde etkisi görülmüştür. Kısıtlılık uygulaması olup olmamasına göre tüketicilerdeki marka imajının algılanan rekabete etkisinin farklılaştı̆̆ı söylenebilir. Tüketiciler tepkisel satın alma davranışlarını tepkisel satın alma eğiliminin eyleme dair yanının etkileriyle gerçekleştirmiştir. Başkalarıyla aralarında rekabet algılayan tüketicilerin tepkisel satın alma eğilimlerinin bilişsel ve psikolojik reaksiyon sergileme eğiliminin hem bilişsel hem de eyleme dair yanlarının rekabet algılamalarına etkisi olmuştur. Tüketicilerin hem memnuniyet hem de uyarılma duygu durumlarına markete yönelik değerlendirme ve psikolojik reaksiyon sergileme eğiliminin hem bilişsel hem de eyleme dair yanlarının etkileri vardır. Memnuniyet duygu durumlarına marka kalite algısı da etki yapmıştır. Markaya göre kalite algısı tüketicilerin miktar kısıtlılığı deneyimlediği koşullarda başkalarılla aralarında rekabet algılamalarına etkili olmuştur. Markaya göre kalite algısının memnuniyet ve uyarılma duygu duruma sadece zaman kısıtlılığı koşulunda etkili olduğu söylenebilir. Markaya göre sadece miktar kısıtlılığını yaşayan tüketicilerdeki marka kalite algısı ve başkalarıyla aralarında rekabet algılamalarının tepkisel satın alma davranışlarına güdüleyici tesirli etkisi belirtilebilir. Ve bu etki markaya göre farklılaşmaktadır. Tüketicilerin uyarılma duygu durumlarına markaya dair tutumlarıyla, tepkisel satın alma eğilimlerinin eyleme dair yanlarının anlamlı etkisi bulunduğu söylenebilir. Uyarılma duygu durumlarının da tepkisel satın alma eğilimlerinin bilişsel yanlarının başkalarıyla aralarında rekabet algılamalarına anlamlı güdüleyici etkisi olduğu söylenebilir. Tüketicilerin başkalarıyla aralarında algıladıkları rekabetin tepkisel satın alma davranışlarına anlamlı güdüleyici etkisi işaret edilebilir.

Memnuniyetin tepkisel satın alma davranışına dair etkilerine yönelik araştırma bulguları Verplanken ve Herabadi (2001) ile Gardner ve Rook (1988) çalışmasında ifade edilenlerle ilişkili, Mishra ve Mishra (2010) çalışmasının zıttı şekilde görüldüğü ifade edilebilir. Uyarılma duygu durumun tepkisel satın alma ilişkisi Herabadi ve ekibinin (2009) çalışması değerlendirmeleriyle ilintilidir. Tüketicilerin miktar kısıtlılığı ile karşılaştıkları durumda tepkisel satın alma deneyimlemeleri Kim (2014), Lee (2012) ve Aggarwal vd. (2011) çalışmasındaki ürün miktar kisıtlılığ1 durumunda tepkisel satın alma davranışı deneyimlenmesi bulgularınla ilintili görülmüştür. Zaman kısıtlılığ1 koşulunda markaya göre tepkisel satın alma davranışının nispeten azalabiliyor olması Kim (2014) ve Lee (2012) 


\section{F. İ. Konyalıŏlu - A. Şekerkaya 12/4 (2020) 3518-3538}

çalışma bulguları ile desteklenebilmektedir. Tepkisel satın alma davranışının markaya göre değişkenlik gösterebiliyor olduğu bahsi Kacen ve Lee (2010) çalışması ile desteklenebilmektedir. Ürün markası imajının tepkisel satın alma davranışı ilişkilendirilmesi bahsi Spears (2001) çalışması bulgularıyla ilintili olarak ifade edilebilmektedir.

Çalışmanın bulguları bazı önerilerin sunulmasına olanak sağlamaktadır. Tüketiciler kısıtılık koşulları ilişkili psikolojik reaksiyon şeklinde tepkisel satın alım yapmaktadırlar. Psikolojik reaksiyon bağlamında tepkisel satın alma davranışı sergilenmesine dair özellikle, ürün miktar kısıtlılığı ve kısıtlılık olmayan koşullarda bulgular edinilmiştir. Pek çok araştırma ve pazarlama stratejisi olarak kısıtlılık koşullarının böylesi satın almayı getireceği düşünülürken bulgular ışığında farklı yaklaşımın önemine işaret etmek gerekir. Kısıtlılık koşullarındansa tüketiciler kısıtsız koşullarda kendilerine satın alma avantajı olarak sunulabilecek satış tutundurma uygulamaları ile böylesi satın alma yapabilirler. Kısıtlılığın tüketicilerde 'Bumerang' etkisi gibi psikolojik reaksiyon olarak ürünü satın almak noktasından nispeten uzaklaşma getirebileceğinin göz önünde bulundurulması gerekir. Markaya göre tüketicilerin kisıtlılık koşulundan etkilenerek psikolojik reaksiyon şeklinde tepkisel satın alma davranışlarının farklılaşabildiği üstünde gerekenlerdendir. İşletmeler markaya göre kısıtlılık koşullarının, kısıtlılık koşulu türünün psikolojik reaksiyon şeklinde tepkisel satın alma yapılmasının farklılaşacağına özellikle dikkat etmelidirler. İşletmelerin kısıtlılık koşulları ve markaya göre farklılaşmalar olacağı gibi tüketicilerin duygu durumları, eğilimleri ve kişisel değerlendirmelerinin etkilerine dikkat edilmesi gereklidir. Memnuniyet duygu durumundan, uyarılmaya, markaya ve mağazaya yönelik olumlu değerlendirmelerden kişisel eğilimlere kadar pek çok değişken psikolojik reaksiyon ilişkili tepkisel satın alma davranışına etki etmektedir. Araştırma sonuçlarına göre memnuniyet ve uyarılma duygu durumları tepkisel satın alma davranışının gelişiminde bilfiil entegre ifade edilebilirken, rekabet algısının birlikte değişim göstermediği durumu işaret edilebilir. İşletmeler pazarlama stratejileri geliştirirken bu ayrımı göz önünde bulundurmalıdırlar.

Çalışmada incelenen konuların eş veya benzer yöntemlerle farklı kültürel yapılarda uygulanmasıyla farklı sonuçlar alınabilme durumu kısıtlarından biridir. Ürün çeşidi, katılımcıların belirli bir sosyoekonomik seviyeden olması bir diğer kısıt olarak ifade edilebilir. İleride yapılacak araştırmalara yönelik öneri sunulsa, farklı ürünler ve fiyat indiriminden başka düzenleyici değişken ile çalışılması durumunda yeni sonuçlara ulaşılabileceği görülebilir. Araştırma modeli, deney değişkenlerinin çeşitlendirilmesi ve çoklu disiplinlerin bir araya getirilebilmesiyle kuram ve strateji geliştirilebilmesi mümkün olabilir. Dijital mecra üzerinden yapılabilecek eş veya ilişkili araştırmalar da hem bilimsel hem de işletmeler açısından değerli katkılar sağlayabilir.

\section{Kaynakça}

Aaker, D. A. (1996). Building Strong Brands, The Free Press, New York.

Adelaar, T., Chang, S., Lancendorfer, K. M., Lee, B. and Morimoto, M. (2003). Effects of Media Formats on Emotions and Impulse Buying Intent, Journal of Information Technology, 18 (4), 247-266.

Aggarwal, P., Jun, S. Y. and Huh, J. H. (2011). Scarcity Message: A Consumer Competition Perspective, Journal of Advertising, 40 (3), 19-30.

Aggarwal, P. and Vaidyanathan, R. (2003). Use It or Lose It: Purchase Acceleration Effects of Time-Limited Promotions, Journal of Consumer Behavior, 2 (4), 393-403.

Akturan, U. (2009). Tüketicilerin Cinsiyetlerine İlişkin Olarak İçgüdüsel Alısveriş Eğilimlerindeki Farklılıkların Belirlenmesi: Üniversite Öğrencilerine Yönelik Pilot Bir Araştırma, Yönetim Dergisi, 20 (64), 62-77.

Baumeister, R. F. (2002). Yielding To Temptation: Self-Control Failure, Impulsive Purchasing and Consumer Behavior, Journal Of Consumer Research, 28 (4), 670-676.

Baun, D. and Klein G. A. (2003). Joy and Suprise as Guides to a Better Understanding of Impulse Buying Behavior, European Advances in Consumer Research (Eds.), Darach Turley, Stephen Brown, Provo UT: Association for Consumer Research in Europe, 6, 290-299. 


\section{F. İ. Konyalıŏlu - A. Şekerkaya 12/4 (2020) 3518-3538}

Bayley, G. and Nancarrow, C. (1998). Impulse Purchasing: A Qualitative Explanation of The Phenomenon, Qualitative Market Research, An International Journal, 2 (1), 99-114.

Beatty, S. E. and Ferrell, E. M. (1998). Impulse Buying: Modeling It's Precursors, Journal of Retailing, 74 (2), 169-191.

Bell, D. R., Corsten D. and Knox, G. (2011). From Point of Purchase to Path to Purchase: How Preshopping Factors Drive Unplanned Buying, Journal of Marketing, 75 (1), 31- 45.

Bellenger, D. N., Robertson, D. H. and Hirschman, E. C. (1978). Impulse Buying Varies by Product, Journal of Advertising Research, 18 (6), 15-18.

Berman, B. and Evans, J. R. (2012). Retail Management: A Strategic Approach, Twelveth Edition, Pearson Prentice Hall. USA.

Bessarabova, E., Fink, E. L. and Turner, M. (2013). Reactance, Restoration, and Cognitive Structure: Comparative Statics, Human Communication Research, 39 (3), 339-364.

Bolton, R. N. and Drew J. H. (1991). A Multistage Model of Customers' Assessments of Service Quality and Value, Journal of Consumer Research, 17 (4), 375-384.

Bray, J. (2008). Consumer Behaviour Theory: Approaches and Models, e-Book, Bournemouth University.

Brehm, J. W. (1966). A Theory of Psychological Reactance, Academic Press Inc. . Massachusetts.

Brock, T. C. (1968). Implications of Commodity Theory for Value Change. In Grewald A. (Eds.) Timothy Brock, Thomas M., Ostrom, Psychological Foundations of Attitudes, New York: Academic Press, 243-275.

Byun, S.E. and Sternquist, B. (2012). Here Today, Gone Tomorrow: Consumer Reactions to Perceived Limited Availability, Journal of Marketing Theory and Practice, 20 (2), 223-234.

Byun, S.E. and Sternquist, B. (2011). Fast Fashion and In-Store Hoarding: The Drivers, Moderator, and Consequences, Clothing \& Textiles Research Journal, 29 (3), 187-201.

Byun, S.E. (2006). Here Today, Gone Tomorrow: The Antecedents and Consequences of In-Store Hoarding At Fast Fashion Stores, A Dissertation Submitted to Michigan State University in Partial Fulfillment of The Requirements for The Degree of Doctor of Philosophy Department of Advertising, Public Relations and Retailing.

Cialdini, R. B. (1993). Influence: Science and Practice, Third Edition, New York: Harper Collins. New York.

Clee, M. A. and Wicklund, R. A. (1980). Consumer Behavior and Psychological Reactance, Journal of Consumer Research, 6 (4), 389-405.

Cohen, J. B., Pham, M. T. and Andrade, E. B. (2008). The Nature and Role of Affect in Consumer Behavior, Handbook of Consumer Psychology (Eds.) Curtis P. Haugtvedt, Paul Herr, Frank Kardes, 297-348, Erlbaum.

Devlin, J., Ennew, C., McKechnie, S. and Smith, Andrew (2007). A Study of Time Limited Price Promotions, Journal of Product \& Brand Management, 16 (4), 280-285.

Dinçer, C. (2010). The Influence of Affect and Cognition on Impulse Buying Behavior, Öneri Dergisi, 9 (33), 153158.

Dodds, W. B. (1996). Perceived Value: A Dimension of the Consumer Risk Construct, Mid-American Journal of Business, 11 (1), 15-23.

Gardner, M. P. (1985). Mood States and Consumer Behavior: A Critical Review, Journal of Consumer Research, 12 (3), 281-300.

Gardner, M. P. and Rook D. W. (1988). Effects of Impulse Purchases on Consumers' Affective States, Journal of Advances in Consumer Research, 15, 127-130. 


\section{F. İ. Konyalığlu - A. Şekerkaya 12/4 (2020) 3518-3538}

Gardner, M. P., Wansink, B., Kim, J. and Park, S. B. (2014). Better Moods for Better Eating?: How Mood Infleunces Food Choice, Journal of Consumer Psychology, 24 (3), 320-335.

Gierl, H., Plantsch, M. and Schweidler, J. (2008). Scarcity Effects on Sales Volume in Retail, The International Review of Retail, Distribution and Consumer Research, 18 (1), 45-61.

Gierl, H. and Huettl, V. (2010). Are Scarce Products Always More Attractive? The Interaction of Different Types of Scarcity Signals with Products' Suitability for Conspicuous Consumption, International Journal of Research in Marketing, 27, 225-235.

Grewal, D., Monroe, K. B. and Krishnan, R. (1998). The Effects of Price-Comparison Advertising on Buyers' Perceptions of Acquisition Value, Transaction Value and Behavioral Intentions, Journal of Marketing, 62, 46-59.

Grewal, D. and Sharma, A. (1991). The Effect of Salesforce Behavior on Customer Satisfaction: An Interactive Framework, Journal of Personal Selling \& Sales Management, 11 (3), 13-23.

Grossman, H. I. and Mendoza, J. (2003). Scarcity and Appropriative Competition, European Journal of Political Economy, 19, 747-758.

Gupta, S. (2013). The Psychological Effects of Perceived Scarcity on Consumers' Buying Behavior, A Dissertation Submitted to University of Nebraska in Partial Fulfillment of The Requirements for The Degree of Interdepartmental Area of Business (Marketing) -Doctor of Philosophy.

Hair, J. F. Jr., Black, W. C., Babin, B. J. and Anderson, R. E. (2010). Multivariate Data Analysis, Pearson. London.

Hansen, F. (1969). Consumer Choice Behavior: An Experimental Approach, Journal of Marketing Research, 6, 436443.

Hausman, A. (2000). A Multi-Method Investigation of Consumer Motivations in Impulse Buying Behavior, Journal of Consumer Marketing, 17 (5), 403 - 426.

Heath, C. B. (2006). Scarcity: Two Alternative Conceptions of The Self A Conceptual and Historical Analysis, Loyola University Chicago, A Dissertation Submitted to The Faculty of The Graduate School in Candidacy for The Degree of Doctor of Philosophy Program in Philosophy by Chicago.

Herabadi, A. G., Verplanken, B. and Van Knippenberg, A. (2009). Consumption Experience of Impulse Buying in Indonesia: Emotional Arousal and Hedonistic Considerations, Asian Journal of Social Psychology, 12, $20-31$.

Kacen, J. J., Hess, J. D. and Walker, D. (2012). Spontaneous Selection: The Influence of Product and Retailing Factors on Consumers Impulse Purchases, Journal of Retailing and Consumer Services, 19 (6), 578-588.

Kacen, J. J. and Lee, J. A. (2002). The Influence of Culture on Consumer Impulsive Buying Behavior, Journal of Consumer Psychology, 12 (2), 163-176.

Kahneman, D. (2011). Thinking Fast and Slow, Macmillan. London.

Kapferer, J. N. (2008). The New Strategic Brand Management, Forth Edition, Kogan Page, London.

Khan, M. T., Humayun, A. A. and Sajjad, M. (2015). Factors Affecting Impulse Buying and Percentage of Impulse Buying in Total Purchasing, International Journal of Information, Business and Management, 7 (1), 254-268.

Kim, J. Y. (2014). Impulse Buying: The Effect of Decision Time and Product Scarcity on Buying Impulse, A Dissertation Submitted to Michigan State University in Partial Fulfillment of The Requirements for The Degree of Retailing-Doctor of Philosophy,

Kirby, K.N. and Hernstein, R. J. (1995). Preference Reversals Due to Myopic Discounting of Delayed Reward, Psychological Science, 6, 83-89. 


\section{F. İ. Konyalıŏlu - A. Şekerkaya 12/4 (2020) 3518-3538}

Kline, R. B. (2011). Princibles and Practice of Structural Equation Modeling, Third Edition, The Guilford Press. New York.

Lee, J.A. and Kacen, J. J. (2008). Cultural Influences on Customer Satisfaction with Impulse and Planned Purchase Decisions, Journal of Business Research, 61 (3), 265-272.

Lee, S. Y. (2012). The Effect of Scarcity on Product Evaluation, A Dissertation Submitted to Desautels Faculty of Management, McGill University in Partial Fulfillment of The Requirements for The Degree of Doctor of Philosophy,

Li, H. (1995). The Influence of Scarcity Messages on Buying Impulse:An Experimental Study of Tv Home Shopping Programs, A Dissertation Submitted to Michigan State University in Partial Fulfillment of The Requirements for The Degree of Doctor of Philosophy Mass Media, Ph.D. Program College of Communication Arts and Sciences.

Liao, S. L., Shen, Y. C. and Chu, C. H. (2009). The Effects of Sales Promotion Strategy, Product Appeal and Consumer Traits on Reminder Impulse Buying Behaviour, International Journal of Consumer Studies, 33, 274-284.

Low, G. S. and Lamb, C. W. Jr. (2000). The measurement and dimensionality of brand associations, Journal of Product \& Brand Management, 9 (6), 350-370.

Malhotra, N. K. (2010). Marketing Research: An Applied Orientation, Sixth Edition, New Jersey, Pearson Education.

Mazis, M. B., Settle, R. B. and Leslie, D. C. (1973). Elimination of Phosphate Detergents and Psychological Reactance, Journal of Marketing Research, 10 (4), 390-395.

Mihić, M. and Kursan, I. (2010). Assessing The Situational Factors and Impulsive Buying Behavior: Market Segmentation Approach, Management, 15 (2), 47-66.

Mishra, A. and Mishra, H. (2010). We Are What We Consume: The Influence of Food Consumption on Impulsive Choice, Journal of Marketing Research, 11 (7), 1129 -1137.

Mittone, L. and Savadori, L. (2009). The scarcity bias, Applied Psychology: An International Review, 58 (3), 453-468.

Montgomery, D. (2009). Design and Analysis of Experiments, Seventh Edition, John Wiley\&Sons Inc.. New York.

Öner, I. (2011). Traditional vs. Organized Retailers' Affect Differences on Impulse Buying Behavior for Healthy vs. Unhealthy Products: A Study on Turkish Students, T.C. Yeditepe University Graduate Institute of Social Sciences, Ph.D. Thesis Submitted to The Graduate Institute of Social Sciences in Fulfillment of The Requirements for The Degree of Ph.D. in Marketing Istanbul.

Peter, J. P. and Olson, J. C. (2010). Consumer Behavior and Marketing Strategy, McGraw Hill. New York.

Peterson, R.L. (2007). Affect and Financial Decision-Making: How Neuroscience Can Inform Market Participants, Journal of Behavioral Finance, 8 (2), 70-78.

Richins, M. L. (1997). Measuring Emotions in the Consumption Experience, Journal of Consumer Research, 24 (2), 127-146.

Rook, D. W. and Fisher, R. J. (1995). Normative Influences on Impulsive Buying Behavior, Journal of Consumer Research, 22 (3), 305-313.

Sasikarn, C. (2012). Exploring the Effects of Scarcity, Impulse Buying and Product Returning Behavior in the Fast Fashion Environment Among Female Fashion Conscious Consumers, M.S. Thesis, The University of North Carolina at Greensboro.

Segal, B. and Podoshen, J. S. (2013). An examination of materialism, conspicuous consumption and gender differences, International Journal of Consumer Studies, 37, 189-198. 


\section{F. İ. Konyalıŏglu - A. Şekerkaya 12/4 (2020) 3518-3538}

Sirohi, N., Mclaughlın, E. D. and Wittink, D. R. (1998). A Model of Consumer Perceptions and Store Loyalty Intentions for a Supermarket Retailer, Journal of Retailing, 74 (2), 223-245.

Solomon, M. R., Bamossy, G., Askegaard, S. and Hogg, M. K. (2006). Consumer Behavior, European Perspective, Third Edition, Prentice Hall. New York.

Spears, N. (2001). Time Pressure and Information in Sales Promotion Strategy: Conceptual Framework and Content Analysis, Journal of Advertising, 30, (1), 67-76.

Stern, H. (1962). The Significance of Impulse Buying Today, Journal of Marketing, 26 (2), 59-62.

Strack, F., Werth, L. and Deutsch, R. (2006). Reflective and Impulsive Determinants of Consumer Behavior, Journal of Consumer Psychology, 16 (3), 205-216.

Tendai, M. and Crispen, C. (2009). In-store shopping environment and impulsive buying, African Journal of Marketing Management , 1 (4), 102-108.

Ünal, S. (2008). İ̧̧ Güdüsel Alışveriş, Detay Yayıncılık. Ankara.

Verplanken, B. and Herabadi, A. (2001). Individual Differences in Impulse Buying Tendency: Feeling and No Thinking, European Journal of Personality, 15, 71-83.

Wansink, B. (1994). The Dark Side of Consumer Behavior: Empirical Examinations of Impulsive and Compulsive Consumption, Advances in Consumer Research, Vol.21, Eds. C. Allen and D. Roedder, John, Provo: UT: Association for Consumer Research, 508.

Wingrove, J. and Bond, A. (1997). Impulsivity: A State as Well as Trait Variable. Does Mood Awareness Explain Low Correlations Between Trait and Behavioural Measures of Impulsivity?, Personality and Individual Differences, 22 (3), 333-339.

Wood, M. (1998). Socio-economic status, delay of gratification, and impulse buying, Journal of Economic Psychology, 19, 295-320.

Zhang, S. ve Fitzsimons, G. J. (1999). Choice Process Satisfaction: The Influence of Attribute Alignability and Option Limitation, Journal of Organizational Behavior and Human Process, 77 (3), 192-214. 